\title{
Marriage and Parenthood as Status and Rights: The Growing, Problematic and Possibly Constitutional Trend to Disaggregate Family Status from Family Rights
}

\begin{abstract}
KATHARINE K. BAKER ${ }^{*}$
There is a growing trend in family law to sever family rights from family status. Courts and legislatures increasingly recognize a variety of different family forms by granting the legal incidents of family relationship (such as civil unions for same-sex couples or de facto parenthood for caretakers), without granting family status (marriage or parenthood per se). This Article explores this trend by unpacking the constitutional treatment of family relationship. It argues that when state constitutions and the Federal Constitution recognize a right to family status (marriage and parenthood per se), they are not only affording people the legal incidents of family relationship, they are honoring an expressive right to a label everyone understands. Yet this Article suggests that legal actors also often feel compelled (possibly even constitutionally compelled) to award the legal incidents of family relationship even in the absence of awarding status because the rights and obligations of family relationships provide critical sources of identity and autonomy for the people in those relationships. This Article concludes that although courts and legislatures may be attracted to the idea of severing rights from status because it seems to protect alternative families without altering traditional family status categories, ultimately this trend to disaggregate rights from status may undermine legal protection of both traditional and nontraditional family relationships.
\end{abstract}

TABLE OF CONTENTS

I. INTRODUCTION 128

II. THE DISAGGREGATION OF FAMILY STATUS FROM FAMILY RIGHTS (AND OBLIGATIONS) 134

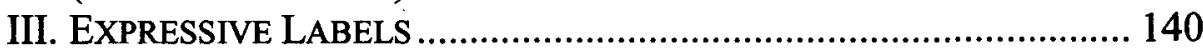

A. Marriage .......................................................................... 140

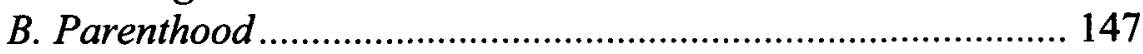

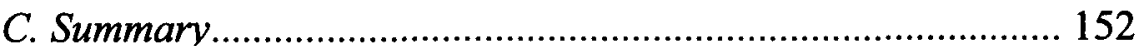

IV. The CONSTITUTIVE RIGHT To RELATIONSHIP ........................... 152

A. The Law and the Importance of the Adult Relationships ....... 155

* Professor, Chicago-Kent College of Law. Many thanks to Anne Dailey, Stephen Heyman, Harold Krent, Michelle Oberman, Mark Rosen, and Kimberley Yuracko for very helpful comments on earlier drafts. Thanks also to Marcia Lehr for exemplary research assistance. 
1. Marriage as Constitutive ................................................... 155

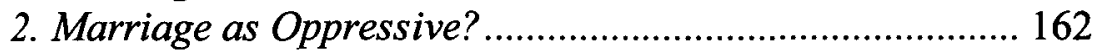

B. The Law and the Importance of Parental Relationships....... 167

1. Parenthood as Constitutive .............................................. 167

2. The Parallels to Marriage................................................ 170

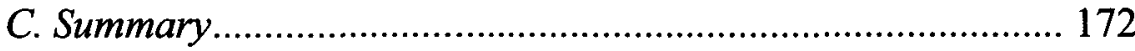

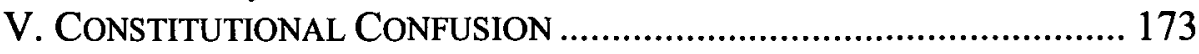

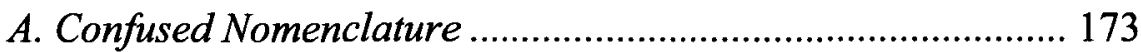

B. A Due Process Requirement? ................................................ 175

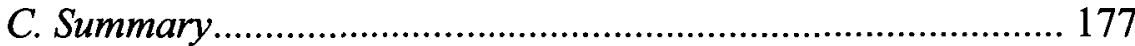

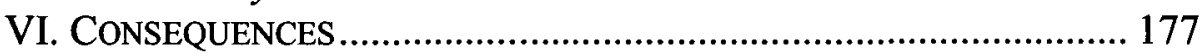

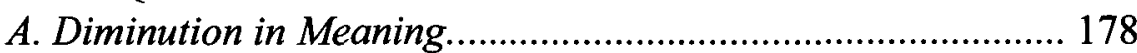

B. Diminution in Burden, Diminution in Benefit ........................ 180

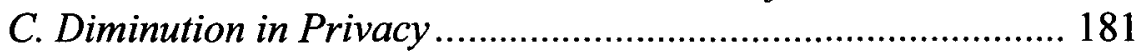

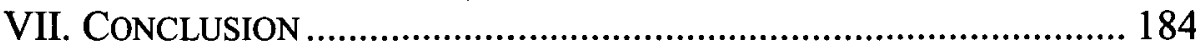

\section{INTRODUCTION}

In May of 2008, the California Supreme Court held that same-sex partners had a constitutional right to marry. ${ }^{1}$ In November of 2008 , the voters of California voted to amend the constitution to define marriage as between a man and a woman. ${ }^{2}$ In May of 2009 , deciding to uphold that voter referendum, the California Supreme Court held that same-sex couples had a fundamental right to "establish... an officially recognized family relationship," 3 but not a fundamental right to the name marriage itself. In doing so, the Supreme Court of California disaggregated family rights from family status, finding a constitutional right to the former even while accepting the voters' ability to restrict access to the latter.

${ }^{1}$ In re Marriage Cases, 183 P.3d 384, 399 (Cal. 2008) ("[The] core substantive rights [of marriage] include... the opportunity of an individual to establish ... an officially recognized and protected family [that is] ... entitled to the same respect and dignity ... as marriage.").

2 The voter referendum was generally known as Proposition 8. See Proposimion 8, TEXT OF PROPOSED LAWS, 129 (2008), http://voterguide.sos.ca.gov/past/2008/general/ text-proposed-laws/text-of-proposed-laws.pdf\#prop8 [hereinafter PROPOSITION 8].

3 "Proposition 8 reasonably must be interpreted in a limited fashion as eliminating only the right of same-sex couples to equal access to the designation of marriage, and as not otherwise affecting the constitutional right those couples to establish an officially recognized family relationship." Strauss v. Horton, 207 P.3d 48, 76 (Cal. 2009). 
By disaggregating rights from status in this way the California court was following a trend, not only for courts challenged by the same-sex marriage question, but in family law generally. In the course of the last thirty years, courts and legislatures have often distilled the rights associated with family relationships from the traditional names or statuses associated with those relationships. Non-traditional family structures have put increasing pressure on the law and private parties to recognize different kinds of family relationships. In response, the law has started to grant alternative family members rights, without granting them family status.

Consider the well-known case of Michael H. ${ }^{4}$ Michael $\mathrm{H}$. was the wealthy, worldly young man who bounced between homes in Los Angeles and St. Thomas, sometimes with the married woman with whom he was having an affair, sometimes with the child born as a result of the affair, but not always or in any permanent sense with either of them. Michael $\mathrm{H}$. went to court claiming a constitutional right to parental status, just as plaintiffs in the same-sex marriage cases have claimed a constitutional right to marital status. Michael, like many of the same-sex marriage plaintiffs, was denied a right to family status, but he did not go home empty handed. Justice Stevens, the swing vote in Michael $H$. v. Gerald $D$., voted to deny Michael the status of father because whatever the rights that his biological connection and relationship to his daughter gave him, they were honored by a state statute that allowed him to petition for visitation rights. ${ }^{5}$ In other words, Michael was denied parental status but not necessarily all the rights of parenthood. Comparably, same-sex couples have often won the right to the legal incidents of marriage, with civil unions and domestic partnerships, but been denied marital status.

Plaintiffs like Michael H. and the same-sex couples who argue that they have a constitutional right to family status do not always lose. ${ }^{6}$ Constitutional doctrine suggests that there are fundamental rights to both marital and parental status, but those rights are limited, cabined by the social meaning of the terms marriage and parenthood. Constitutional doctrine also suggests that the law may be compelled to recognize family rights even if it does not grant family status. Constitutions may protect rights to be treated as in relationship with another as a legal matter. This latter protection is what Michael H. and

${ }^{4}$ Michael H. v. Gerald D., 491 U.S. 110 (1989).

5 There was much dispute about whether someone like Michael actually could obtain visitation rights under the California statute. The dissent read the existing California family law precedent as precluding Michael from being awarded visitation against the mother's wishes. It is unclear what the four dissenters would have ruled if they had believed, as Justice Stevens did, that Michael had a reasonable chance of being awarded visitation - though not parental status-over the mother's objection.

${ }^{6}$ See infra Parts III.A \& III.B. 
many of the gay and lesbian plaintiffs went home with, even if it was not all that they wanted.

The trend to disaggregate rights from status does not always have a constitutional dimension. Sometimes judges, legislatures, and private actors grant rights in the absence of status even if there is no recognized constitutional need to do so. One can remain agnostic on the question of whether state or federal constitutions mandate recognition of family relationship rights even in the absence of recognizing family relationship status, and still acknowledge that many legal actors feel an affirmative duty to honor relationship rights even in the absence of family status. ${ }^{7}$

Conferring family status bestows on someone the legal rights and obligations accompanying that status, but it also honors the expressive value implicit in labeling. Conferring the legal rights and obligations of relationship honors the constitutive benefits that flow from being connected to another. The ability to disaggregate legal incidents from status allows courts and legislatures to recognize alternative relationships without necessarily disrupting the social meaning of either marriage or parenthood. This Article explores the legal dimensions of family status and family rights, explains how they are different, and analyzes the potential problems with disaggregating them.

Critical to the analysis presented here is the recognition that, legally, marriage and parenthood are comparable institutions. To date, few scholars have embraced the links between the legal treatment of marriage and parenthood. Some scholars have clearly separated them, assuming or stating that they have nothing to do with each other. ${ }^{8}$ I argue that isolating the legal

${ }^{7}$ For the most part, this Article collapses the distinctions between the federal and state constitutions because they are not relevant to the arguments made here. First, the relationship between a state constitution and state family law is essentially the same as the relationship between the federal Constitution and state family law. The constitutional challenge to a state's family law, whether brought under a state or federal constitution, involve the same kinds of constitutional values, the same analysis of the same precedents and the same balance of power issues. See Lewis v. Harris, 908 A.2d 196, 206-08, 22122 (N.J. 2006) (using U.S. Supreme Court cases to define the term liberty and analyze questions of scrutiny, and emphasizing the importance of deferring to legislature); Goodridge v. Dep't of Pub. Health, 798 N.E.2d 941, 956-60 (Mass. 2003) (discussing what it means for something to be a civil right and analyzing questions of scrutiny using U.S. Supreme Court cases); Baker v. State, 744 A.2d 864, 870-73 (Vt. 1999) (discussing principle of equality, following U.S. Supreme Court guidance on questions of scrutiny, and discussing importance of deferring to legislature). Collapsing the federal/state distinction allows one to proceed with a constitutional analysis without having to filter through the different political and social perspectives that clearly do distinguish many state supreme courts from the federal one.

${ }^{8}$ Anita Bernstein writes that " $[\mathrm{m}]$ arriage is different... from the other key status category of family law-parenthood-in that the relation between parent and child 
treatments, particularly the constitutional treatment, of marriage and parenthood from each other makes little sense. The vast majority of cases to ever discuss the constitutional dimensions of either parenthood or marriage refer to parenthood and marriage together, as if the rights are clearly akin to each other. ${ }^{9}$ Traditionally, marital status determined parental status and the existence of parental rights was contingent on the state of one's marriage. And, even though parental rights are usually cast as negative rights and marital rights are usually cast as positive rights both sets of rights are usually protected for the same reasons.

The Article proceeds as follows. Part II provides a brief description of what has been happening to claims for family recognition in the last thirty years. It describes the various ways courts and legislatures have embraced the disaggregation of family rights from family status in both the marital and parental contexts. "Domestic partnerships" and "civil unions," "de facto parents" and "equitable parents" are now widely used legal constructs that treat people as entitled to the rights (and sometimes liable for the obligations) of legally recognized relationships. The proliferation of these new legal

addresses a relatively clear and uncontroverted need. Infants cannot survive without resources from adults." Anita Bernstein, For and Against Marriage: A Revision, 102 MiCH. L. REV. 129, 132 (2003). Not one of the cases addressing the right to parental status involved children's needs though. In all but one case in which a man has claimed a right to parental status, the child's needs were being readily met by both the mother and another man. See Michael H., 491 U.S. at 115; Lehr v. Robertson, 463 U.S. 248, 250 (1983); Caban v. Mohammed, 441 U.S. 380, 380 (1979); Quilloin v. Walcott, 434 U.S. 246,247 (1978). In the one case when there was not another man to provide for the child, the state was claiming a desire to do so. See Stanley v. Illinois, 405 U.S. $645,649-50$ (1972). Cass Sunstein compares state conferral of marital status with parental status and assumes (wrongly, I think) that parental status is afforded substantially more protection. "If I am the biological parent of a child, the state must have an extremely good reason to sever my relationship with that child." Cass Sunstein, The Right to Marry, 26 CARDOzo L. REV. 2081, 2104 (2005). Presumably, Sunstein was referring to the clear and convincing evidence the state must have of abuse and neglect before terminating a preexisting parent's legal status as parent, but all of the cases just cited involved biological fathers and Michael $\mathrm{H}$. was a biological father who also had an established relationship with his child. In all of those cases, the court vested parental status in someone else simply because the state thought that would be in the best interest of the child.

${ }^{9}$ See, e.g., Zablocki v. Redhail, 434 U.S. 374, 385 (1978) ("[1]t is clear that among the decisions that an individual may make without unjustified government interference are personal decisions relating to marriage, procreation, contraception, family relationships, and child rearing and education.") (quoting Carey v. Population Servs., 431 U.S. 678, 684-85 (1977) (citations omitted)); Cleveland Bd. of Educ. v. LaFleur, 414 U.S. 632, 639-40 (1974) ("This Court has long recognized ... freedom of personal choice in matters of marriage and family life."); Meyer v. Nebraska, 262 U.S. 390, 399 (1923) ("[T] he right of the individual ... to engage in any of the common occupations of life, to acquire useful knowledge, to marry, establish a home and bring up children."). 
categories demonstrates how the law has responded to the need to treat people as in relationship legally, even as the law has resisted expanding the traditional legal statuses of marriage and parenthood.

Part III explores the expressive value of marital and parental status. It examines why people may have an interest in the expressive value of marriage and parenthood and how and why courts have protected rights to those statuses. The expressive value of marriage is more obvious, both in practice and in the cases, than the expressive value of parenthood. But when analyzed together it becomes clear that the ability to claim either marital or parental status has expressive value. Because of the immensely meaningful role that family relationships play in our individual and collective lives, access to the family status label is very important to people. Thus, while no one refutes a state's ability to regulate aspects of marriage and parenthood, the cases strongly suggest that a state must be careful in restricting access to those labels. If an individual's relationship comports well enough with the social understanding of family status, he or she is constitutionally entitled to express him or herself through that status.

Part IV explores why and how the law protects not just marital and parental status but relationships that are akin to marriage and parenthood. Drawing on psychological and philosophical theories of relationship, as well as on the constitutional doctrine of family relationships, Part IV argues that the legal incidents of marriage and parenthood are recognized legally for similar reasons. They are recognized because being entwined with another legally, economically, morally, and socially has such a profound effect on who one is, what one wants and how one sees oneself in the world. When the law bestows the rights and obligations that treat one as in family relationship with another, the law honors the liberty associated with being able to exist with another as a unitary entity.

Part $\mathrm{V}$ elaborates on how the constitutional nomenclature surrounding the family, in particular the rhetoric of rights involving intimacy, privacy and autonomy has fostered confusion in this area, thus further obfuscating the status/incidents distinction. Part V then explores in some more detail why there might be a substantive due process right to the legal incidents of family relationship, even in the absence of a right to family status.

Part VI will argue that the tendency to disaggregate both marital and parental rights from marital and parental status jeopardizes the traditional constitutional protection of families. First, to the extent we value the expressive benefits associated with assuming family status, those benefits will dissipate as alternative family statuses proliferate. Getting married and being a parent will likely not mean the same thing if there are many other kinds of marriage-lite and parent-lite arrangements available. Some may view the availability of more family options as a positive development, but if nothing else, the same-sex marriage debate shows that many people on both 
the right and left side of the political spectrum want to retain some of the traditional expressive dimension of marriage.

Second, courts and legislatures have shown themselves much more willing to confer rights than impose obligations on non-traditional family members. By diminishing the legal responsibilities associated with family relationships, courts and legislatures diminish the constitutive nature of family relationships. The less formative and defining a relationship is to one's selfhood, the less it needs any legal protection at all. The need to recognize certain relationships because they are so important to the people in them diminishes if relationships come to be seen more as voluntary associations that bring with them rights and benefits but no responsibilities or obligations.

Third, the more legally varied and individuated family-like relationships become, the more necessary it will be for courts to insert themselves inside those relationships to ascertain individual rights and responsibilities. The more courts insert themselves inside some family relationships, the less likely courts will be to honor notions of relationship privacy and autonomy for all family relationships.

The recent legislative activity embracing same-sex marriage ${ }^{10}$ and many public opinion polls showing increasing support for same-sex marriage ${ }^{11}$ suggest that the social meaning of marriage is changing. Enough people in enough places will soon believe that marriage is not essentially heterosexual. Once that happens, there will be less need to disaggregate marital rights from marital status because same-sex couples will have access to marital status. But before same-sex marriage is fully recognized, many states will probably adopt an intermediary disaggregative position. States that cling to traditional definitions of marriage will adopt civil unions and domestic partnership regimes before they adopt marriage.

Comparably, courts and legislature will probably continue to grant parental rights without granting parental status. ${ }^{12}$ As with marriage, it may be that the pressure to disaggregate is greatest in those political communities that most resist changing traditional family definitions. For instance, courts

${ }^{10}$ Legislative bodies in Vermont, New Hampshire, and Maine have all voted to recognize same-sex marriages. See The Human Rights CAMPaign, Marriage \& RELATIONSHIP RECOGNITION, http://www.hrc.org/issues/marriage.asp. The voters in Maine then rejected the legislative action. See Election Results 2009, N.Y. TIMES, Nov. 9, 2009, http://elections.nytimes.com/2009/results (follow "Other National Races" hyperlink).

11 See Paul Steinhauser, CNN Poll: Generations Disagree on Same-Sex Marriage, CNN.com, May 4, 2009, http://www.edition.cnn.com/2009/US/05/04/ samesex.marriage.poll/index.html.

12 Many academic commentators endorse the idea of expanding rights without necessarily expanding status. See infra note 41 . 
in states that neither recognize any form of same-sex union nor allow second parent adoptions, often award visitation and custody to non-biological, samesex partners. The recognition of either the same-sex partnership or the adoption would give the partner parental status and thus the automatic right to petition for visitation and custody. Yet several courts have found that the failure of the legislature to confer parental status is irrelevant to the question of whether the non-biological same-sex partner is entitled to parental rights. ${ }^{13}$ These courts thus make a clear distinction between family status and family rights. They award the latter even if the legislature has resisted conferring the former.

Providing family rights without providing family status in this way may seem like a cautious, intermediary step, but in the end this Article suggests that it may be a move that does more to threaten traditional constitutional protection of relationship than honor it.

\section{The DisaggRegation OF FAMILy StatUS FROM FAMILY RIGHTS (AND OBLIGATIONS)}

In the past thirty years, it has become abundantly clear that many people, not just people in traditional family relationships, very much want the law to treat them as in relationship with a significant other. When asking for legal recognition of their relationships, these people do not make contract claims. They do not claim an entitlement based on an agreement with another. They make situational claims, or claims of entitlement based on the nature of their emotional and physical connection to another. ${ }^{14}$

${ }^{13}$ Mason v. Dwinnell, 660 S.E.2d 58, 64 (N.C. Ct. App. 2008) ("[W]e find immaterial Dwinnell's arguments that she and Mason could not marry, and Mason could not adopt the child under North Carolina law."); T.B. v. L.R.M., 786 A.2d 913, 918-19 (Pa. 2001) ("The ability to marry the biological parent and the ability to adopt the subject child have never been and are not now factors in determining whether the third party assumed a parental status and discharged parental duties.").

14 By situational, I mean claims based on their lives as lived, not on explicit or implicit agreements. One example of this is the affidavit that the University of California previously used to determine entitlement to domestic partner benefits: "We are each other's sole domestic partner and intend to remain so indefinitely. We are in a relationship of mutual support, caring, and commitment. We are financially interdependent." Grace Blumberg, The Regularization of Nonmarital Cohabitation: Rights and Responsibilities in the American Welfare State, 76 NOTRE DAME L. REV. 1265,1289 (2001) (citing language from the old affidavit). The University of Califomia has since adopted a new form that changes the language but ultimately has the same effect. DeClaration of Domestic ParTnership, UNIVERSITY of California, UBEN 250, http://atyourservice.ucop.edu/forms_pubs/forms_worksheets/uben250.pdf ("We are each other's sole domestic partner in a long-term, committed relationship and intend to remain so indefinitely."). 
For reasons that have a great deal to do with the United States's "shadow" or "employee" welfare state, many of the initial claims to rights in the partner context were made in the private sector. They were made by employees who wanted to give their partners access to the considerable array of welfare benefits that, in the United States, are provided by employers to employees and their families. ${ }^{15}$ Notably, these claims were made predominantly by same-sex cohabitants, not by opposite sex cohabitants, even though opposite sex cohabitants outnumber their gay counterparts by a significant margin. ${ }^{16}$ Opposite sex couples may not have pushed as hard for these benefits because they knew their claims would ring hollow given their option to marry, or, they may not have pushed hard because they actually did not want them. If they had wanted to be treated as a unit by the outside world, they could marry. It was the same-sex couples who had no other means of being treated as one.

The first employer to offer domestic partner benefits to its employees was the Village Voice in 1982.17 In 1992, Lotus Development Corporation became the first publicly traded company to do so. ${ }^{18}$ By 2001 , more than 2500 public and private employers extended health care benefits to domestic partners. ${ }^{19}$ These plans cannot be viewed as purely private agreements. Although the federal government has so far refused to confer the same tax advantages on same-sex couple plans as it does on plans covering married couples, ${ }^{20}$ government policy-makers routinely rely on private employer plans when they design health care plans. ${ }^{21}$ The availability of these plans lets people who might not otherwise have a reasonable chance of obtaining health insurance coverage do so. ${ }^{22}$

15 These benefits include health and disability insurance and access to retirement plans. In most other industrialized countries, these types of claims would be made in the public sector because it is the state that plays the primary role in providing social insurance programs.

16 See Blumberg, supra note 14, at 1286.

17 See Human Rights Campaign, Domestic Partner Benefits, http://www.hrc.org/ issues/workplace/benefits/domestic_partner_benefits.htm (last visited Feb. 7, 2010).

$18 \mathrm{Id}$.

19 Id.

20 I.R.S. Priv. Ltr. Rul. 200339001 (Sept. 26, 2003).

${ }^{21}$ None of the major health care reform proposals involve dispensing with employer-based health care completely.

22 Most of these employer-based programs confer benefits without requiring significant obligation. To the extent these plans confer pension rights, they often do not require that an employee share pension accumulation with their ex-partner in the event of separation. See Blumberg, supra note 14, at 1291-92. Married people, in contrast, are required to share pension benefits. Although there is virtually always fighting about how 
At the same time employers were beginning to recognize same-sex relationships in the private sector, same-sex marriage advocates were beginning their campaign for legally recognized gay marriage. In the last eighteen years, same-sex marriage advocates have successfully argued that gays and lesbians are constitutionally entitled to marital status in five states. $^{23}$ Just as important, they have forced courts and legislatures to articulate what same-sex couples are entitled to if they are not entitled to marital status.

The state of Hawaii, after its supreme court ruled that the state equal rights amendment forbade the state from prohibiting gays and lesbians from marrying each other, brokered a kind of compromise in which the voters approved a constitutional amendment defining marriage as "between a man and a woman," but the state legislature passed domestic partner legislation allowing two people who could not marry each other the right to register as domestic partners. ${ }^{24}$ In Baker v. State ${ }^{25}$ and Lewis v. Harris, ${ }^{26}$ the supreme courts of Vermont and New Jersey required their state legislatures to pass legislation that allowed gay and lesbian couples access to a fully equal set of relationship rights and obligations as those available to straight couples. ${ }^{27}$ New Jersey explicitly found it permissible to deny opposite sex couples access to the marriage label. ${ }^{28}$ Vermont implied the same thing, but did not

much should be shared and why, every state in the country gives a divorcing spouse a claim to pension rights earned by the other spouse during the course of the marriage.

${ }^{23}$ Hawaii found the right to marry as a matter of gender equality, Baehr v. Lewin, 852 P.2d 44, 63-67 (Haw. 1993), but a subsequent voter initiative restricted marriage to opposite-sex couples. Connecticut and Iowa found that gays and lesbians were a suspect class and that restrictions on same-sex marriage constituted impermissible discrimination on the basis of sexual orientation. Kerrigan v. Comm'r, 957 A.2d 407, 426-28 (Conn. 2008); Varnum v. O'Brien, 763 N.W.2d 862, 889-906 (Iowa 2009). The Massachusetts Supreme Judicial Court relied little on either fundamental rights or equality jurisprudence, holding that in the family law area the doctrines were inextricably intertwined and that there was no rational reason to restrict marriage to opposite couples anyway. Goodridge v. Dep't of Pub. Health, 798 N.E.2d 941, 953, 961 (Mass. 2003). The California case In re Marriage Cases was significantly altered by Proposition 8 and the subsequent judicial interpretation of what that meant. See Strauss v. Horton, 207 P.3d 48, 76 (2009).

24 See Blumberg, supra note 14, at 277-78.

25 Baker v. State, 744 A.2d 864 (Vt. 1999).

26 Lewis v. Harris, 908 A.2d 196 (N.J. 2006).

${ }^{27}$ Both courts decided this as a matter of equality doctrine, but the equality analysis did not extend to the label "marriage."

${ }^{28}$ Lewis, 908 A.2d at 211 ("[W]e cannot find that a right to same-sex marriage is so deeply rooted in the traditions, history, and conscience of the people of this State that it ranks as a fundamental right."). 
technically reach the question. ${ }^{29}$ After Proposition 8 and Strauss v. Horton 30 California's law now operates as New Jersey's does. ${ }^{31}$

The Connecticut state legislature, aware that same-sex marriage litigation was pending, voted without any court mandate to extend full civil union benefits to same-sex couples. ${ }^{32}$ New Hampshire, Maine, and Washington D.C. also adopted extensive domestic partnership protection before their legislatures voted to sanction same-sex marriage. ${ }^{33}$ In addition, Oregon, Washington and hundreds of municipalities have adopted some form of domestic partner legislation. ${ }^{34}$ The effects of these domestic partnership provisions vary. They can, but do not always, give the full panoply of marital state rights and obligations. Municipal regulations operate more like private employer recognition of same-sex relationships because they involve few, if any, tax, property and future income consequences.

The American Law Institute's Principles of the Law of Family Dissolution ${ }^{35}$ also recommends treating couples who do not acquire marital status as being legally in relationship to each other. Although some have criticized these provisions for denying couples who do not want to be treated as an entity the freedom to be single, ${ }^{36}$ the ALI has recommended treating

${ }^{29}$ Baker, 744 A.2d at 886 ("We hold ... that plaintiffs are entitled ... to obtain the same benefits and protections afforded by Vermont law to married opposite-sex couples. We do not purport to infringe upon the prerogatives of the Legislature to craft an appropriate means of addressing this constitutional mandate...."). Vermont subsequently became the first state to legislate same-sex marriage without being ordered to do so by the state supreme court. See Abby Goodnough, Rejecting Veto, Vermont Backs Gay Marriage, N.Y. TIMES, Apr. 8, 2009, at A1.

30207 P.3d 48, 76 (2009); see also Proposition 8, supra note 2.

31 Though in California, same-sex couples have both a fundamental right and an equality right to all the legal incidents of marriage. See Strauss, 207 P.3d at 75-78.

32 The Connecticut Supreme Court subsequently required the state to recognize marriage, on the theory that separate could not be equal. See Kerrigan, 957 A.2d at 418 20.

33 See Lambda Legal, Status of Same-Sex Relationships Nationwide as of December 1, 2009, http://www.lambdalegal.org/publications/articles/nationwide-status-same-sexrelationships.html.

${ }^{34}$ See $i d$. for a summary of state legislation giving same-sex couples some form of relationship status, but not marriage.

35 See AMERICAN LAW InSTITUTE, PRINCIPLES OF THE LAW OF FAMILy DisSOlUTION: ANALYSIS AND RECOMMENDATIONS $\S \S 6.01-6.06$ (2002) [hereinafter ALI PRINCIPLES].

36 See Elizabeth Scott, Domestic Partnerships, Implied Contracts and Law Reform, in RECONCEIVING THE FAMILY: CRITIQUES ON THE AMERICAN LAW INSTITUTE'S PRINCIPLES OF THE LAW OF FAMILY DisSOLUTION 331, 332 (Robin Fretwell Wilson ed., 2006) [hereinafter Reconceiving ThE FAMILY]; see also Margaret Brinig, Domestic Partnership and Default Rules, in RECONCEIVING THE FAMILY, supra, at 269; Marsha 
non-married people who have not contracted around the background rules of marriage as if they were married. This treatment includes, importantly, holding both parties economically accountable to the other in the event of dissolution. Both property and compensatory payments (traditionally known as maintenance or alimony) are to be awarded to domestic partners in accordance with the same principles as those used in the marriage context. ${ }^{37}$ In other words, the law is supposed to treat people as married even though they do not have the legal label of marriage.

In the parental arena, there has been a comparable and mostly concurrent trend. In part because adults tend to drift into and out of relationships more than they used to, in part because DNA testing allows us to determine genetic parentage with certainty, in part because artificial insemination has become so much more readily available, and in part because gay and lesbian parenting has become less taboo, ${ }^{38}$ non-traditional parents now routinely petition courts for parental rights. And sometimes, legal parents petition courts in order to hold non-traditional parents liable for parental obligations. ${ }^{39}$ Grandparents, step-parents and other third parties often enjoy statutorily protected rights to visitation, ${ }^{40}$ and numerous scholars have called for a more expansive, less exclusive view of parenthood, one that leaves room for the law to recognize many different kinds of adult relationships in a child's life. ${ }^{41}$

Garrison, Marriage Matters: What's Wrong with the ALI's Domestic Partnership Proposal, in RECONCEIVING THE FAMILY, supra, at 305.

37 See ALI PRINCIPLES, supra note 35, at §§ 6.05-6.06.

38 For more on how all of these factors are forcing the law to come to terms with what it thinks the defining features of parenthood should be, see generally Katharine $\mathrm{K}$. Baker, Bionormativity and the Construction of Parenthood, 42 GA. L. REV. 649 (2008) [hereinafter Baker, Bionormativity].

${ }^{39}$ See Katharine K. Baker, Bargaining or Biology? The History and Future of Paternity Law and Parental Status, 14 CORNELl J.L. \& PUB. POL'Y 1, 15-16 (2004) [hereinafter Baker, Bargaining or Biology?].

40 See, e.g., Twyla J. Hill, Legally Extending the Family: An Event History Analysis of Grandparent Visitation Rights Laws, 21 J. FAM. Issues 246, 247-48 (2000) ("Grandparent visitation rights laws were enacted in all 50 states over a period of 23 years."); Margaret Mahoney, Stepparents as Third Parties in Relation to Their Stepchildren, 40 FAM. L.Q. $81,104 \mathrm{n} .82$ (2006) ("The visitation statutes in a number of states include stepparents under an umbrella provision that authorizes visitation petitions by 'any person.' .... In other jurisdictions, the unrestricted category of stepparents is specifically included in the visitation statute."). These rights must be treated as somewhat secondary to parental rights, but they are still cognizable. See Troxel v. Granville, 530 U.S. 57, 64-67 (2000). A host of grandparent visitation statues have been upheld even after Troxel.

${ }^{41}$ Katharine T. Bartlett, Rethinking Parenthood as an Exclusive Status: The Need for Legal Alternatives When the Premise of the Nuclear Family Has Failed, 70 VA. L. 
In response to these trends, many courts have developed "de facto parent" doctrines, "equitable parent" doctrines, and "parenthood by estoppel" doctrines. ${ }^{42}$ Usually these doctrines involve giving non-traditional parents visitation rights. Less often, they involve holding non-traditional parents liable for child-support. As in the cohabitation area, the American Law Institute has called for legal recognition of these alternative parenting relationships. Advocating the adoption of both a "de facto parent" class and a "parenthood by estoppel" doctrine, the ALI supports an expansion of parental rights and, far more rarely, parental responsibility. ${ }^{43}$ In short there has been widespread creation of legally cognizable parental relationships, even in people who do not have the legal label of parent. ${ }^{44}$

This Article's analysis of the dual dimensions of the legal treatment of relationship helps explain the widespread tendency to disaggregate relationship rights from relationship status. As family structures proliferate, something compels the law to recognize them even as something else restricts the law's embrace of them. As Part III will argue, what keeps courts and legislatures from embracing many different kinds of marriage and multiple forms of parenthood is an allegiance to the social meaning of the institutions of marriage and parenthood. That social meaning is not fixed, but neither is it infinitely capacious. People only have a right to those institutions and to the expressive potential implicit in their labels if those individuals' situations comport to the social understanding of those terms.

The law has been far more willing to legitimate claims for family rights though. It has been willing to treat two people as one and force others to do the same. ${ }^{45}$ It has been willing to award visitation rights to people who never

REV. 879, 944-62 (1984) (suggesting that legal notions of parenthood should be expanded for families that don't live as a traditional nuclear family); Naomi R. Cahn, Reframing Child Custody Decisionmaking, 58 OHIO ST. L.J. 1, 49-55 (1997) (advocating the designation of many adults as "parents"); Barbara Bennett Woodhouse, Hatching the Egg: A Child-Centered Perspective on Parents' Rights, 14 CARDOZO L. REV. 1747, 1827-44 (1993) (advocating a more care-based approach to parental rights).

42 See Baker, Bionormativity, supra note 38, at 698.

43 For more on the asymmetrical way in which the ALI treats parental rights and responsibilities, see Katharine K. Baker, Asymmetric Parenthood, in RECONCEIVING THE FAMILY, supra note 36 , at $121-28$.

44 The ALI Principles of Family Dissolution leave the determination of legal parenthood to someone else. One comment explains that determinations of legal paternity are "a matter outside the scope of these Principles." ALI PRINCIPLES $\S 3.03 \mathrm{cmt}$. d, at 472 . It is not clear why the ALI drafters felt comfortable passing over the question of legal parentage (e.g. parental status) while embracing the task of determining parental-like rights and obligations. See Baker, supra note 43, at 126-27.

45 This is what many aspects of domestic partnerships and civil unions do. 
enjoyed the legal status of parent and never attempted to get it. ${ }^{46}$ Although initially resistant, ${ }^{47}$ many legal actors now feel compelled to honor most family relationships as lived, even if they do not feel compelled to change the definition of marriage and parenthood as legally defined. Parts III and IV explore why.

\section{EXPRESSIVE LABELS}

\section{A. Marriage}

As virtually every court ${ }^{48}$ and commentary ${ }^{49}$ to have engaged the question of same-sex marriage has noted, there are numerous material and nonmaterial legal incidents of marriage. The legal incidents of marriage, for the most part, define the variety of ways in which the law requires the government and private actors to treat married people as a unit. But most people probably do not get married to secure the legal incidents of marriage. They get married because the act of getting married and being married conveys widely understood messages of unity and commitment. ${ }^{50}$

Getting married-as opposed to just living together or making a promise to one's partner-signifies a greater commitment in part because it is public (it is harder to break a promise that everyone knows one has made), in part

46 See E.N.O. v. L.M.M., 711 N.E.2d 886, 888-91, 894 (Mass. 1999) (awarding visitation rights to a non-biologically related lesbian co-parent); J.A.L. v. E.P.H., 682 A.2d 1314, 1319-22 (Pa. 1996) (same); ALI PrINCIPLES, supra note 35, at $\S 2.18$ (describing de facto parent doctrine).

47 The early gay marriage cases did not fare well. See Baker v. Nelson, 191 N.W.2d 185,185 (Minn. 1971) (denying gay male couple the right to marry), appeal dismissed, 409 U.S. 810 (1972); Alison D. v. Virginia M., 572 N.E.2d 27, 28-30 (N.Y. 1991) (denying non-biologically related lesbian co-parent any visitation or custody rights). Several more state high courts have also resisted more recent claims to gay marriage. See, e.g., Conaway v. Deane, 932 A.2d 571, 581 (Md. 2007) (denying any right to same-sex marriage); Hernandez v. Robles, 855 N.E.2d 1, 5 (N.Y. 2006).

48 See, e.g., Lewis v. Harris, 908 A.2d 196, 215 (N.J. 2006); Hernandez, 855 N.E.2d at 6-7; Goodridge v. Dep't of Pub. Health, 798 N.E.2d 941, 955-56 (Mass. 2003); Baker v. Vermont, 744 A.2d 864, 870 (Vt. 1999).

${ }^{49}$ See Bernstein, supra note 8, at 146-52; David Chambers, What If? The Legal Consequences of Marriage and the Legal Needs of Lesbian and Gay Male Couples, 95 MiCH. L. REV. 447, 452-85 (1996); Sunstein, supra note 8, at 2090-92.

50 There is little question that, on average, those who commit to each other through marriage end up making a more binding commitment than those who commit to each other without getting married. See Garrison, supra note 36, at 308 (citing studies showing that only $10 \%$ of cohabitants who do not marry are together after five years, whereas $80 \%$ of first marriages survive past five years and $66 \%$ of first marriages survive past ten years). 
because state rules make it more onerous to break, but also because by marrying, people attach themselves to an institution that that is bigger than themselves. Individuals may try to define the terms of their own marriage for each other, ${ }^{51}$ but if they associate themselves with the institution of marriage, their relationship will necessarily be interpreted by outsiders in certain ways.

For instance, it is very likely that others will view a marriage as a relationship involving shared values, shared resources, and significant emotional support. ${ }^{52}$ Any given marriage may not involve these things and the state is limited in the extent to which it can enforce the sharing of these things, but sharing these things is what most people think married people do because that is what marriage means. Thus getting married is a way of sending a message about one's relationship. One sends that message to the world, to one's partner and quite probably to oneself. The ability to send that message and attach oneself to the institution of marriage appears to be enormously important to people. Most people do it and even more people want to do it. ${ }^{53}$ Perhaps for this reason, the Supreme Court has, at times, protected individuals' right to marital status. ${ }^{54}$

51 Many individuals may also not feel this freedom. Social norms exert powerful forces on the parties to a marriage and are likely to make them feel more committed and less free to define the relationship as they want. See Elizabeth Scott, Social Norms and the Legal Regulation of Marriage, 86 VA. L. REV. 1901, 1908-12 (2000).

52 People assume marriages involve this kind of sharing because of the social norms associated with marriage. See id.

53 See infra notes $177-79$ (more than $83 \%$ of women ages $35-44$ have married and even more women express a desire to get married). Because getting married also involves getting a marriage license, marriage involves governmental speech as well. In granting the license, the state says "this relationship is worthy of the rights and obligations that we confer on married people." Gays and lesbians fighting for the right to marry are claiming a right to have the government legitimate their relationship too, but the arguments they have recently used as to why the government should do so have been rooted in the personal expressive value that marriage provides to the people who marry. See infra text accompanying notes 71-78.

54 See Loving v. Virginia, 388 U.S. 1, 2 (1967). Two of the three state courts that have successfully awarded same-sex couples the label "marriage" have done so as a matter of equality, not fundamental rights theory. See Varnum v. O'Brien, 763 N.W.2d 862, 889-96 (Iowa 2009); Kerrigan v. Comm'r, 951 A.2d 407, 418-20 (Conn. 2008). That is, same-sex couples have been more successful in claiming a right to the marriage label because straight couples have it than in claiming an independent right to the label itself. California originally said there was a fundamental right to the label marriage, but let that finding be overturned by Proposition 8 . See supra text accompanying note 2 ; infra notes 77-78 and accompanying text. The Supreme Judicial Court of Massachusetts, in the first state supreme court decision to mandate same-sex marriage, said that equal protection and fundamental rights analysis were inextricably intertwined and therefore it was not important to separate them, but Massachusetts also found that the restrictions on same-sex marriage could not pass rational basis review. Thus, the particular 
The United States Supreme Court has decided three different right to marry cases. Richard Loving, a white man, and Mildred Loving, an AfricanAmerican woman, married in the District of Columbia but wanted to reside and stay married in the state of Virginia. ${ }^{55}$ Virginia prohibited interracial marriage. ${ }^{56}$ Roger Redhail wanted to marry his current girlfriend even though he was in arrears on a child support obligation owed to a child he had sired, while a teenager, several years before. ${ }^{57}$ Wisconsin law denied the right to marry to people who could not prove that their preexisting children were "not then and not likely thereafter to become public charges." 58 Leonard Safley was in jail in Missouri and wanted to get married. Prison regulations prevented him from doing so. ${ }^{59}$

The first case, Loving $v$. Virginia, is notorious for being simultaneously straightforward and obtuse. As a matter of equal protection doctrine, the ban on interracial marriage was readily struck down by the Supreme Court because the ban on interracial marriage was a transparent state endorsement of white supremacy ${ }^{60} \mathrm{But}$ in the final three (very short) paragraphs of Loving, the Court declared that marriage was protected by the Due Process Clause because it was one of the "'basic civil rights of man,' fundamental to our very existence and survival." 61 The Court then quickly put in a qualification: "To deny this fundamental freedom [to marry] on so unsupportable $a$ basis as the racial classifications... is surely to deprive ... due process of law." 62 The first part of this short section at the end of the Loving opinion thus seems to suggest that the Constitution protects a right to marry because marriage is so fundamental to existence. The subsequent line qualifies that right by suggesting that denial of the right to marry may be permissible in some instances, but not "on so unsupportable a basis" as race.

constitutional doctrine was not that important. See Goodridge v. Dep't of Pub. Health, 798 N.E.2d 941, 961 (Mass. 2003).

${ }^{55}$ Loving, 388 U.S. at 2.

$56 \mathrm{Id}$. at 4-6.

57 Zablocki v. Redhail, 434 U.S. 374, 377-78 (1978).

$58 \mathrm{Id}$. at 375.

59 Turner v. Safley, 482 U.S. 78, 82 (1987).

60 "The fact that Virginia prohibits only interracial marriages involving white persons demonstrates [the law to be] designed to maintain White Supremacy." Loving, 388 U.S. at 11.

${ }^{61}$ Id. at 12 (quoting Skinner v. Oklahoma, 316 U.S. 535, 541 (1942)). The invocation of Skinner, a case involving sterilization and thus a restriction on parenthood, is another example of the Court referring to marriage and parenthood together, as if the rights are akin to each other. See supra note 9 and accompanying text.

62 Loving, 388 U.S. at 12. 
Eleven years after Loving, Roger Redhail applied for a marriage license and was denied because he owed child support. ${ }^{63}$ As support for the idea that marriage is a fundamental right, the Zablocki majority opinion cited almost every constitutional case having anything to do with parenting, ${ }^{64}$ procreation ${ }^{65}$ marriage, ${ }^{66}$ or other family relationships. ${ }^{67}$ For reasons the Court did not make entirely clear, the totality of all of those cases suggested that there must be a fundamental right to marry.

When Leonard Safley wanted to get married in jail, the Court finally felt compelled to explain what marriage is in a little more detail. Relying only on Zablocki for the idea that there is a fundamental right to marry, the Court tried to explain why. Marriage is an "expression[] of emotional support and public commitment." 68 It "may be an exercise of religious faith as well as an expression of personal dedication." 69 It "often is a precondition to the receipt of governmental benefits, ... property rights, ... and other, less tangible benefits (e.g., the legitimization of children born out of wedlock). ${ }^{.70}$ All of those reasons augured in favor of letting Leonard Safley marry.

63 Zablocki v. Redhail, 434 U.S. 374, 377-78 (1978).

64 Id. at 385 (citing Prince v. Massachusetts, 321 U.S. 158 (1943) (state's parens patriae interest in children must be balanced against parents' rights to raise children as they believe appropriate); Pierce v. Soc'y of Sisters, 268 U.S. 510 (1925) (right of parents to send children to private school); Meyer v. Nebraska, 262 U.S. 390 (1923) (right of parents to hire someone else to teach children a language other than English)).

65 Zablocki, 434 U.S. at 385 (citing Carey v. Population Servs. Int'l, 431 U.S. 678 (1977) (right to abortion); Cleveland Bd. of Educ. v. LaFleur, 414 U.S. 632 (1974) (right not to be fired for being pregnant); Roe v. Wade, 410 U.S. 113 (1973) (right to abortion); Eisenstadt v. Baird, 404 U.S. 438 (1972) (right of non-married people to contraception)).

66 Zablocki, 434 U.S. at 384-85 (citing Loving v. Virginia, 388 U.S. 1 (1967); Griswold v. Connecticut, 381 U.S. 479 (1965) (finding that married couples have a right to privacy that includes the right to contraceptives); Skinner v. Oklahoma, 316 U.S. 538 (1942) (prohibiting mandatory sterilization)).

${ }^{67}$ Zablocki, 434 U.S. at 385 (citing Smith v. Org. of Foster Families for Equal. \& Reform, 431 U.S. 816 (1977) (rights of foster parents); Moore v. City of E. Cleveland, 431 U.S. 494 (1977) (rights of non-nuclear family to live together)).

68 Turner v. Safley, 482 U.S. 78, 95 (1987) (emphasis added).

69 Id. at 96 (emphasis added).

${ }^{70} \mathrm{Id}$. This last item explicitly invokes the legal incidents of marriage, not marriage's expressive value, though the last "benefit," the legitimization of children, is a particularly weak argument because for the most part, by this time, states were not allowed to treat illegitimate children differently than legitimate children. See generally IRA ELLMAN, Paul Kurtz, Elizabeth Scott, lois Weithorn \& Brian Bix, Family LaW: CaSes, TEXT, PROBLEMS 1035-38 (4th ed. 2004) (describing the evolution of the constitutional doctrine on illegitimate children). Legitimating could be accomplished by simply signing a birth certificate or acknowledging paternity. See also UNIFORM PARENTAGE ACT, $\S \S 201,204$ (2000). 
The expressive qualities of marriage, noted explicitly first by the Turner Court, have been particularly important to the constitutional treatment of same-sex marriage recently. In Baker v. State,$^{71}$ the Vermont Supreme Court acknowledged the symbolic importance of marriage, though it curiously determined that marriage's symbolism was not at issue, writing that it was the 'plaintiffs' claim to the secular benefits and protections of . . [marriage] ... that . . characterize[d] this case."72 In other words, the court determined that there was an expressive component of marriage that was distinct from the panoply of rights and benefits marriage affords.

In Goodridge v. Department of Public Health, the Supreme Judicial Court of Massachusetts highlighted the expressive aspects of marriage in granting the right to same-sex marriage. The first line of the opinion reads simply: "Marriage is a vital social institution." "I3 It noted that marriage is a function of "community" 74 and that it is "at once a deeply personal commitment to another human being and a highly public celebration ...."75 No doubt, the Massachusetts court emphasized the expressive value in order to explain why it was going further and requiring marriage in a way that the Supreme Court of Vermont did not in Baker.

The New Jersey plaintiffs in Lewis v. Harris adopted the Massachusetts Court's rhetoric, arguing that "marriage is the ultimate expression of love, commitment and honor you can give to another human being .... [O]thers know immediately that you have taken steps to create something special."76 The Supreme Court of New Jersey did not deny the expressive value of marriage, but found that it was not protected for gays and lesbians under either the substantive due process or equal protection clauses of the New Jersey Constitution. ${ }^{77}$

In In re Marriage Cases, California became the first and only state court to find that same-sex couples had a fundamental right to the marriage label. ${ }^{78}$ Same-sex couples already had the full panoply of domestic partnership

${ }^{71}$ Baker v. Vermont, 744 A.2d 864, 888-89 (Vt. 1999).

72 Id. at 889 . It is not at all clear why the court decided that the plaintiffs were not asking for the symbolic aspects of marriage itself. The dissent appeared to think the plaintiffs were asking for the symbolic aspects of marriage. added).

73 Goodridge v. Dep't of Pub. Health, 798 N.E.2d 941, 948 (Mass. 2003) (emphasis

${ }^{74}$ Id. at 949 (marriage is "one of our community's most rewarding and cherished institutions.").

75 Id. at 954 (emphasis added).

${ }^{76}$ Lewis v. Harris, 908 A.2d 196, 225-26 (N.J. 2006) (Poritz, C.J., concurring and dissenting) (quoting plaintiffs' affidavit) (emphasis added).

77 Id. at $211,215$.

${ }^{78}$ In re Marriage Cases, 183 P.3d 384, 434 (Cal. 2008). 
rights, but the Supreme Court of California held that gays and lesbians had a fundamental right to marry because the marriage label commanded the respect and dignity of others. ${ }^{79}$ It was because of the positive way that others view people with marital status that the California court said marriage was a fundamental right. ${ }^{80}$

The idea that marriage has an important expressive dimension is also evident from the way scholars discuss it. As David Chambers argued in his support of gay marriage, "marriage is the single most significant communal ceremony of belonging." 81 Carol Sanger notes that civil marriage "is a convention that signals an acceptance of certain obligations. It does so publicly (often ceremonially) and as a matter of law."82 Cass Sunstein has argued that the right to marry counts as fundamental only "because of the expressive benefits that come from official, state-licensed marriage." 83

That marriage must serve some kind of expressive function becomes clear once one looks at the history of marriage. Every state and every religious tradition, at least for the last 600 years, has required that a witness

79 " $[O]$ ne of the core elements of this fundamental right [to marry] is the right of same-sex couples to have their official family relationship accorded the same dignity, respect and stature as that accorded to all other officially recognized family relationships." Id. at 434 .

80 The Supreme Court of California wrote:

The current statutes-by drawing a distinction between the name assigned to the family relationship available to opposite-sex couples and the name assigned to the family relationship available to same-sex couples, and by reserving the historic and highly respected designation of marriage exclusively to opposite-sex couples ... pose a serious risk of denying the official family relationship of samesex couples the equal dignity and respect that is a core element of the constitutional right to marry.

Id. at 434-35. After Proposition 8, the California Court decided that same-sex couples still had a fundamental right to the legal incidents of marriage, though not a fundamental right to the label itself. See Strauss v. Horton, 207 P.3d 48, 76 (Cal. 2009). In essence, the court conceded what this article argues, which is that the right to a family status label is cabined by social norms regarding the social meaning of that status. Proposition 8 clarified the social norms.

As mentioned, lowa and Connecticut rooted the right to marry in equality principles. See Varnum v. Brien, 763 N.W.2d 862, 876 (Iowa 2009); Kerrigan v. Comm'r of Pub. Health, 957 A.2d 407, 421 (Conn. 2008). This allowed the California court to speak less about the nature of marriage itself and more about discrimination. Massachusetts did not reach the question of whether there was a fundamental right to same-sex marriage. See Goodridge v. Dep't of Pub. Health, 798 N.E.2d 941, 953, 961 (Mass. 2003).

81 Chambers, supra note 49 , at 450.

${ }^{82}$ Carol Sanger, A Case for Civil Marriage, 27 CARDozo L. REv. 1311, 1317 (2006).

${ }^{83}$ Sunstein, supra note 8, at 2098. 
be present at the marriage ceremony. ${ }^{84}$ Marriage, unlike other promises that we might ask the law to regulate, cannot be made "just" between two people. Others must be there. One needs to find a justice of the peace or a judge or minister even if one does not want a party with friends or family.

Common law marriage, the equitable legal doctrine through which courts conferred marital status on people who cohabited and acted as if they were married, has always required the parties to hold themselves out to the public as married. ${ }^{85}$ Historian Nancy Cott entitled her comprehensive review of American marriage "Public Vows." 86 If marriage were only about privacy, as the Supreme Court's rhetoric sometimes suggests, ${ }^{87}$ then none of these public requirements would make any sense. The ubiquitous public requirements of marriage suggest that at some fundamental level marriage is about making a statement to others.

Expressive potential is necessarily limited by social meaning, however. Getting married makes a statement because of what people understand marriage to mean. Commitment is a part of that meaning, but it is not necessarily the only part of that meaning. The totality of the social meaning of marriage is indubitably informed by historical understanding. Marriage simply would not mean the same thing if it were created yesterday.

84 See George P. MONGER, MARRIAGe CuStoms of THE WORLD: From HenNa to HONEYMOONS 60 (2004) ("The most important thing [about a wedding ceremony] is that it be public."); Edith Tumer \& Pamela R. Frese, Marriage, in 8 ENCYCLOPEDIA OF RELIGION 5726 (Lindsay Jones ed., 2d ed. 2004) ("Two elements are used to mark a marriage, whether there is a ceremony or not: the sharing of food between the bride and groom ... and the necessity of a public statement or the requirement of witnesses."). In Catholic history, the requirement that a priest be present at the ceremony started out as a custom, but later became a requirement. MARY ANN GLENDON, THE TRANSFORMATION OF FAMILY LAW 24 (1989). The Jewish tradition asks at least two or three witnesses to sign the Ketubah as evidence of their witnessing the promise. See MONGER, supra, at 177-78. Muslim ceremonies also require witnesses. Id. at 170. Every state in this country requires someone, either an agent of the state or of a religious faith or some third party specially deputized for the task to be present at the marriage ceremony. It simply is not marriage if there is not someone else there.

85 See, e.g., In re Estate of Dallman, 228 N.W.2d 187, 190 (Iowa 1975) (“[O]ne element essential to the proof of [common law marriage] is a general and substantial 'holding-out' or open declaration thereof to the public... [T] common law marriage.").

86 NANCY COTt, PUblic Vows: A History OF MARRIAGE AND the NATION (2000).

87 See, e.g., Griswold v. Connecticut, 381 U.S. 479, 485 (1965) (holding that married couples enjoy a privacy right that entitles them to use contraception). In Part IV, I suggest that marital privacy includes a right to be treated as an autonomous marital entity, but in this Part, I argue that the Constitution also protects a right to marriage as expression. This right cannot be considered a privacy right because it is inherently public. 
Thus, to the extent that the constitution protects people's ability to secure marital status because marriage serves as a form of expression, that protection must be limited by social meaning. What "others know immediately" 88 about the statement of marriage depends on what others think marriage is, and that social understanding is not fixed. Marriage means something different today than it did 100 years ago. To some, that contemporary meaning is clearly capacious enough to include gay men and lesbians. ${ }^{89}$ To others, it is not. ${ }^{90}$ The fundamental rights language in Loving suggests that interracial marriage, even if nowhere near normative, was not inconsistent enough with the social meaning of marriage to permit states to ban it. ${ }^{91}$ The plaintiffs in Zablocki and Turner were entitled to marital status because what they were claiming was a right to express themselves through a very traditional form of marriage. As Sunstein notes, "the expressive benefits of marriage are contingent on a particular constellation of social norms; there is nothing inevitable about them."92

\section{B. Parenthood}

The Supreme Court cases addressing parental status suggest that the rights of people to secure parental status are also "contingent on a particular constellation of social norms." 93 For the most part, parentage, like marriage, is a question of state law. State parentage acts determine who enjoys presumptions of parenthood (a woman giving birth to a child, for instance, or a man married to that woman, or a man listed on a birth certificate), and what procedures, if any, exist for rebutting those presumptions. ${ }^{94}$ State law also

88 See supra text accompanying note 76; Lewis v. Harris, 908 A.2d 196, 226 (N.J. 2006) ("[O]thers know immediately that you have taken steps to create something special.").

${ }^{89}$ See Steinhauser, supra note 11 (describing a poll showing how many Americans believe that same-sex couples should be allowed to marry); see also Goodridge, 798 N.E. $2 \mathrm{~d}$ at 961 (finding no rational reason to restrict marriage to opposite sex couples).

90 See, e.g., Lewis, 908 A.2d at 208, 211 (accepting New Jersey's right to define the social meaning of marriage in heterosexual terms). As suggested, the voters defined the social meaning of marriage in California when they passed Proposition 8. See supra note 77.

91 Sunstein, supra note 8, at 2103.

92 Id. at 2098.

${ }^{93} \mathrm{Id}$.

94 Virtually all states have parentage acts establishing not only presumptions of parenthood, but means of contesting those presumptions. Today, most states allow most presumptions of parenthood to be rebutted with DNA evidence, but the ability to do so can be limited temporally both by statutes of limitations, see, e.g., CAL. FAM. CODE $\S \S 7540-41$ (2004) (giving those who wish to challenge a presumption of paternity two 
determines when a parent can be displaced as a parent, by whom, and when. ${ }^{95}$ For years, state statutes have assigned paternal status in cases of artificial insemination ${ }^{96}$ and state statutes now routinely designate who should be considered the mother in cases of surrogacy. ${ }^{97}$

Nonetheless, the Supreme Court has recognized some constitutional right to be declared a parent. In 1972, Peter Stanley, who had lived with his three biological children and their mother for most of the children's lives, challenged an Illinois dependency statute that presumed children to be parentless if their unwed mother was dead. ${ }^{98}$ The Court held that the Constitution guaranteed a man who had "sired and raised" 99 his children, an opportunity to be heard before the state could declare his children wards of the state. Thus, the Constitution seemed to protect Stanley's right to the legal status of father.

years from the discovery of relevant facts), and estoppel principles. See In re Paternity of Cheryl, 746 N.E.2d 488, 496-97 (Mass. 2001) (holding non-biological father responsible for child support because he continued to fill the role of father even after acquiring reason to believe he was not the father); Markov v. Markov, 758 A.2d 75, 81 (Md. 2000) (denying husband right to challenge paternity because he accepted role as father despite having had a vasectomy before the children were born).

95 See, e.g., UNIFORM PARENTAGE ACT $\S \S 607,609$ (2000). As a preliminary indication of how complicated parentage questions can become, the first Comment to the Act notes "[f]our separate definitions of 'father' are provided by the Act to account for the permutations of a man who may be so classified." Id. $\S 102 \mathrm{cmt}$. (Supp. 2009). The Uniform Act generally requires that claims to establish paternity be brought within two years of the child's birth, id. $\S 607$, or two years of an acknowledgement of paternity, id. $\S 609$. Actions to disestablish paternity of a presumed father may be brought at any time, but only if the presumed father never had sex with the mother at the probable time of conception and never held himself out as father. $I d$. $\S 607$. The cases make clear that courts' willingness to change a presumed father's status is very fact-specific. A genetic father can sometimes displace a presumed father, but not always. A presumed father can sometimes relinquish his status if he can find the biological father or if the biological father willingly comes forward. On the other hand, if two men are competing for the status of father (or competing not to be the father) courts often disregard biology altogether and use a Best Interest of the Child standard to determine paternity. See Baker, Bargaining or Biology?, supra note 39, at 12-14.

96 See, e.g., UNIFORM PARENTAGE ACT, supra note 95 , $\S \S 704,705$. Often, these statutes make a distinction between formal inseminations performed by a licensed physician and those performed informally. The husband of the impregnated woman is considered the father if the insemination was done by a licensed physician, but not necessarily if it was not. See, e.g., CAL. FAM. CODE $\S 7613$ (2003).

97 See Institute for Law Science and Technology, The Laws of Reproductive Technology, available at http://www.kentlaw.edu/islat/reprotech.html.

98 Stanley v. Illinois, 405 U.S. 645,646 (1972).

99 Id. at 651 . 
Several years later, Leon Quilloin tried to block the adoption of the eleven-year-old child he had sired (though never lived with) using a comparable claim: the Constitution guaranteed him rights as a father, including the right to keep someone else from becoming the father, because Quilloin had sired the child, periodically paid child support, and seen the child on occasion. ${ }^{100}$ The Supreme Court readily dismissed Quilloin's claim, finding that whatever constitutional interest Quilloin had in being a father was adequately protected at a Best Interest of the Child hearing in which a judge found that the child's best interest would be served by vesting fatherhood in someone else. Quilloin was stripped of his status as father. ${ }^{101}$

A potential father named Robert Lehr tried again. He argued that the biological mother of his two-year-old girl had prevented him from developing any kind of relationship with the girl and that fact, coupled with his biological connection and his willingness to assume parental responsibility, should guarantee him the right to block the child's adoption by another man. ${ }^{102}$ The Court said no, finding that Lehr's failure to develop a relationship, even if it was due to the mother's intransigence, minimized any constitutional claim he might have. The Court explained: "Parental rights do not spring full-blown from the biological connection between parent and child. They require relationships more enduring." 103 The state court was free to vest fatherhood in someone else.

In 1989, Michael H. seemed poised to capitalize on the idea that one's constitutional right to status as father turned on the twin requirements of biology plus relationship. Michael $H$. could establish that he was the biological father of a child, Victoria, whom he had lived with from time to time, who called him Daddy, and whom he had supported (though others had

100 Quilloin v. Walcott, 434 U.S. 246, 247, 251 (1978)

101 Id. at 253.

102 Lehr v. Robertson, 463 U.S. 248, 250-52 (1983).

103 Id. at 260 (quoting Caban v. Mohammed, 441 U.S. 380, 397 (1979) (Stewart, J. dissenting) (emphasis omitted)). Caban involved a successful claim for paternal status, though the Court decided the case as a matter of sex discrimination. Id. at 394. Mr. Caban was trying to block the adoption of his children by another man, but what distinguished him from Quilloin was that he had developed a much more extensive relationship with his children. See id. at $393 \&$ n.14. Given that relationship between father and children, the Supreme Court held that the mother and father were similarly situated and that therefore the adoption statute could not treat mothers and fathers differently for purposes of securing their consent to adoption. The Lehr Court's subsequent decision strongly suggests that the relationship Mr. Caban developed with his children strengthened a constitutionally protected liberty interest in his children as well as his equal protection claim. See Lehr, 463 U.S. at 267-68 (describing how a father's actual relationship with his child strengthens his liberty interest in paternal status for due process purposes and makes him similarly situated to the mother for equal protection purposes). 
as well) throughout her life. The Court nonetheless rejected Michael's assertion that he had a constitutional right to be declared the father, ${ }^{104}$ finding that the state was free to vest paternal status in the husband of the biological mother, who had also supported Victoria, who was still married to the mother, and who was willingly accepting paternity. The California statute at issue embodied a centuries-old marital presumption of paternity. ${ }^{105}$ Thus, the Court held that the Constitution did not stand in the way of the state conferring parental status on the husband of the mother in the same way it always had. 106

The potential fathers in these parenthood cases probably wanted more than just status. They wanted the rights, and maybe even the obligations, that accompany parental status. ${ }^{107}$ It is important to underscore though, that particularly at the time these cases were decided, most of these men would have gotten minimal visitation time with their children and no right to major parental decision-making. ${ }^{108}$ Judges routinely gave the vast amount of custodial time and all major decision-making authority to the custodial parent. ${ }^{109}$ Most of what these men were fighting for was the right to be called a father. That parental status entitled one to exclude someone else from having the label father, but little else substantively. Thus, it seems likely that these men cared so much about the label father not because of the rights that accompanied it, but because the label itself had social value and social meaning.

104 Michael H. v. Gerald D., 491 U.S. 110, 121 (1989).

105 See Baker, Bargaining or Biology?, supra note 39, at 22-25 (analyzing the strength of and rationale behind the marital presumption of paternity).

106 As noted in the introduction, though, Justice Stevens, the swing vote, opted against giving Michael the right to parental status because the Califomia statute already provided interested third parties (including Michael) a right to petition for the rights traditionally associated with parenthood. In other words, Justice Stevens thought Michael was entitled to the rights of parenthood, but not necessarily the status. Michael H., 491 U.S. at 133-34 (Stevens, J., concurring in the judgment).

107 Comparably, the plaintiffs in Loving, Zablocki, and Turner probably wanted the rights (and maybe the obligations) of marriage, not just the status. See supra text accompanying notes $60-65$.

108 The exception to this is Stanley, who, because there was no other parent at the time he petitioned, would have enjoyed exclusive parental rights.

${ }^{109}$ See ALI PrINCIPLES, supra note $35, \S 2.08 \mathrm{cmt}$. a ("Traditionally, one parent received custody of a child ... while the other parent was awarded visitation. Visitation [was] ... often quite minimal."); LesLIE J. HARRIS, LeE E. TEITELbaum \& JUNE R. CARBONE, FAMILY LAW 622-23 ("When the best-interest standard first took hold, the courts were convinced that custody needed to be awarded to one, and only one parent .... [T] he participation of the other parent ... depended on the cooperation of the custodial parent. Certainty in decision-making authority was considered essential."). 
Quilloin, Lehr, and Michael H. all suggest limits on the scope of any constitutional right to parental status, but they also all take the question seriously. That is to say, none of them suggest that Stanley was wrongly decided and none of them simply declare that the state is free to confer parental status on whomever it wants, free from any constitutional constraint on the definition of parenthood. In a thoughtful essay, Professor David Meyer has suggested that this limited, though probably existent, constitutional protection of parental status may be analogous to the constitutional treatment of property. ${ }^{110}$ The Constitution forbids states from taking property ${ }^{111}$ even as it gives states the extensive discretion to define it. 112

Virtually everyone concedes that states have the ability to modify the requirements of adverse possession, adopt a different rule for ground water use, or tinker with the rule against perpetuities, even though all of those changes affect property rights. ${ }^{13}$ Comparably, few people question the state's ability to honor, or not, surrogacy contracts; to recognize, or not, second-parent adoption; 114 and to determine, for the most part, who is entitled to parental status. This does not mean that states have the right to redefine property or parenthood beyond social recognition, however. Just as community expectations, or the social meaning of property, help set limits on state's ability to expand or contract property interests, ${ }^{115}$ "social expectations

110 David D. Meyer, Partners, Care Givers, and the Constitutional Substance of Parenthood, in RECONCEIVING THE FAMILY 47, 61 (Robin Fretwell Wilson ed., 2006).

111 U.S. CONST, amend. V.

112 Cleveland Bd. of Educ. v. Loudermill, 470 U.S. 532, 538 (1985) ("Property interests are not created by the Constitution, 'they are created and their dimensions are defined by existing rules or understandings that stem from an independent source such as state law."' (quoting Bd. of Regents of State Colls. v. Roth, 408 U.S. 564, 577 (1972)); see also Jeremy Paul, The Hidden Structure of Takings Law, 64 S. CAL. L. REV. 1393, 1402 (1991). Property rights serve "twin roles-as protector of individual rights against other citizens, and as safeguard against excessive government interference." Id. at 1415. "To reconcile American Law's double-edged reliance on property concepts, [we] must successfully distinguish between the courts' role as definers and defenders of property rights." Id.

113 See Joseph Singer, Property LaW: Rules, Policies and Practices 953-54 (4th ed., 2006).

114 "Second-parent adoption" is the term of art used to describe adoption by two parents of the same gender. It is called "second-parent" adoption because usually a new parent is adopting without any former parent relinquishing parental rights. See Sharon S. v. Superior Court, 73 P.3d 554, $558 \mathrm{n} .2$ (Cal. 2003).

115 See Thomas W. Merrill, The Landscape of Constitutional Property, 86 VA. L. REV. 885, 939 (2000) (discussing how the Supreme Court's protection of property was 
about the nature of parenthood are likely to apply a constitutional brake on state-law efforts to withdraw and reassign parent status." 116

\section{Summary}

Social expectations about the nature of marriage and parenthood inform the constitutional inquiry with regard to those statuses. Both marital and parental status bring with them rights and obligations, but the statuses have meaning apart from those rights and obligations. People claiming a right to marital or parental status are claiming a right to have their relationship understood by others in certain commonly understood ways. In granting family status, the state itself expresses something (that this is a relationship worthy of state-conferred status), ${ }^{117}$ but it also enables the recipients of the status to proclaim to the world their unique relationship to another person. The analysis of marriage, which is perhaps more readily seen as expression, helps elucidate how claims to parental status are expressive claims also.

Expressive claims to status are necessarily cabined by the social meaning of that status, but nontraditional relationships can put pressure on and force courts to confront that social meaning. Loving recognized the legitimacy of a still very rare form of marriage and Stanley recognized the legitimacy of unwed fatherhood, an even more suspect form of parenthood then than it is now. In each case, though, the courts found that the plaintiffs were entitled to call themselves, respectively, "married" and "parent," notwithstanding the wide discretion that states have to determine access to and the substantive requirements of marriage and parenthood.

\section{The CONSTITUTIVE Right TO RELATIONSHIP}

The legal incidents of marriage and parenthood provide those with rights to them some well-known legal advantages. One gets to visit one's family member in the hospital. If needed, one gets to make decisions on behalf of one's family member. One gets to inherit one's family member's property if the family member dies intestate. There are many benefits attendant upon securing the legal incidents of marriage and parenthood, but those legal incidents can also be seen as thoroughly restrictive.

These are the kind of constraints the law imposes on married people. One loses control over approximately $50 \%$ of all the earnings one brings to the

deeply informed by "general expectations about kinds of interests that are commonly regarded as being property in our society").

116 Meyer, supra note 110 , at 62.

117 See supra note 53. 
marriage. ${ }^{118}$ One significantly curtails one's ability to pursue any nonremunerative life activity, if in so pursuing, one would be unable to meet future support obligations to one's spouse. ${ }^{119}$ One loses the right to mortgage any property held in tenancy by the entirety, unless one's spouse agrees. One loses the right to petition a court to enforce many explicit and implicit agreements between one's spouse and oneself, particularly if those agreements pertained to duties thought intrinsic to the marriage. ${ }^{120}$ One also often loses the right to keep inherited property if that property was used by both parties to the marriage. ${ }^{121}$ One loses the right to testify in court about what one has heard, if one's spouse said it. ${ }^{122}$ In some states, one loses the

118 In non-community property states, this is not technically true because the property is not conceived of as "marital property" until the divorce proceeding, but, at divorce, whether in a community property or equitable distribution regime, all earnings earned during the course of the marriage are considered property subject to distribution at divorce. See ElLMAN ET AL., supra note 70, at 270-76. Most jurisdictions divide marital property approximately evenly at divorce. $I d$. However, sometimes the primary wage earner or the spouse with access to more other resources is left with significantly less than $50 \%$ of the marital property. See In re Marriage of Pierson, 653 P.2d 1258 (Or. 1982) (wife got less than $50 \%$ of the marital property because she came into an inheritance after the couple had split).

119 All states provide for some spousal maintenance in some instances. After some movement away from substantial spousal maintenance awards in the $1970 \mathrm{~s}$ and $80 \mathrm{~s}$, the current trend is toward more substantial maintenance awards. See generally ALI PRINCIPLES, supra note 35, at ch. 5.

120 E.g., Borelli v. Brusseau, 16 Cal. Rptr. 2d 16 (Dist. Ct. App. 1993) (refusing to enforce a promise to leave more money for spouse because for lack of consideration because wife's promise to care for and support her husband was part of her marital duty); Balfour v. Balfour, (1919) 2 K.B. 571 (A.C.) (U.K.) (most agreements between husband and wife are not meant to be enforceable at law). See generally Jill Elaine Hasday, Intimacy and Economic Exchange, 119 HARV. L. REV. 492 (2005) (law does not compensate women for work performed in marriage).

121 In some community property states, inherited property is considered marital property. See HARRIS, TEITELBAUM \& CARBONE supra note 109 , at 48 . Many equitable distribution states treat any commingled property as marital property. For instance, in Illinois "the affirmative act of augmenting nonmarital property by commingling it with marital property" creates a presumption that the nonmarital (inherited) property is subject to distribution as marital property. In re Marriage of Smith, 427 N.E. 2d 1239, 1245-46 (Ill. 1981).

122 The spousal communications privilege treats as privileged any communication made in confidence from one spouse to another as long as the spouses are not accusing the other of wrongdoing. See GEORGE FISHER, EVIDENCE 839-41 (2002). Most jurisdictions extend the privilege to both the communicator and the listener, meaning that either spouse can bar the other from revealing marital confidences. Id. 
right to sue one's spouse in tort, particularly if the tort was unintentional. ${ }^{123}$ Given this formidable-and not even complete-list of restrictions on one's autonomy, one might question why so many people are clamoring for the right to get married. 124

The obligations the state imposes on parents are less numerous, but arguably stricter and more onerous. Once one is a legal parent, one simply loses the right to walk away from that relationship unless the state and the other parent agrees. ${ }^{125}$ One cannot unilaterally divorce one's child. A parent is obligated to support his or her child until the child is at least eighteen years old. If one is a custodial parent - regardless of how the other parent left-one is responsible for physically caring for the child. Failure to do so is a criminal offense. ${ }^{126}$ If one is a non-custodial parent, one loses the right to allocate one's resources for one's children as one chooses. In all states, parental support obligations are set pursuant to rigid guidelines which allocate resources to the child based on a percentage of what the non-custodial parent earns. ${ }^{127}$ The constitutionally protected parental "right to the companionship, care, custody, and management of ... children [may be] an interest far more

123 For a comprehensive discussion of the state of interspousal tort immunity, see generally Carl Tobias, Interspousal Tort Immunity in America, 23 GA. L. REV. 359 (1989).

124 The idea that the acceptance of pre-nuptial agreements allows most of these obligations to be overridden by private contract is much exaggerated. The Uniform Premarital Agreement Act, adopted in the early 1980s, suggested that premarital agreements should be interpreted like other commercial contracts, but many courts and the recent ALI Principles soundly reject that standard, advocating instead some sort of review under the traditional unconscionability standard and/or procedural protections. See ELLMAN ET AL., supra note 70, at 737-68. Unconscionability is defined with reference to what the spouse would be entitled to under the state marital property distribution rules. Id.

125 One cannot effectively relinquish parental rights (put the child up for adoption) unless the other parent relinquishes also. If one legal parent wants to be a parent and the other parent does not, the first parent still has the right to hold the second parent responsible for child support. See Baker, Bargaining or Biology?, supra note 39. Once the child is old enough, even if both parents want to relinquish parental rights, it is highly unlikely the state would accept their relinquishment because it is highly unlikely the child could be adopted.

126 The first parent to abandon a child is not charged with neglect as long as there is someone else to provide for the child. But if the "last parent standing" exercises similar agency, he or she is charged with abandonment and neglect. See ELLMAN ET AL., supra note 70 , at $1127-39$ (discussing general provisions for civil and criminal child abuse and neglect proceedings).

127 See Katharine K. Baker, Supporting Children, Balancing Lives, 34 PEPP. L. REV. $359,362-63$ (2007) (explaining child support guidelines). 
precious than any property right," 128 but there seems much in the law of parenthood that is detrimental to parents' autonomy and property interests.

Why do people care so much about entering into these statuses in which they compromise so much liberty and property? It is not just because of the expressive value that comes from making these commitments. To put it in economic terms, it is not just because when one weighs the benefits of the expressive utility, against the negative utility associated with the restrictions on autonomy and property, one still comes out ahead. It is instead because the restrictions on autonomy and property inform and enrich the relationships involved, thus providing their own form of positive utility. The legal incidents of marriage and parenthood, though sometimes harsh and restrictive, give meaning and content to those relationships and make them, hopefully, independent sources of happiness, autonomy and identity. Thus, the legal restrictions which so obviously inhibit individuals' ability to shape their own lives as individuals help create relationships through which people (re)constitute themselves as something other than individuals.

\section{A. The Law and the Importance of the Adult Relationships}

\section{Marriage as Constitutive}

Contrary to the once popular slogan suggesting that people need relationships the way fish need bicycles, ${ }^{129}$ it is by now conventional psychological wisdom that "[p]eople are constructed in such a fashion that they are inevitably and powerfully drawn together, ... wired for intense and persistent involvements with one another." 130 Most of the pre-eminent latter twentieth-century psychoanalytic theorists constructed and worked within paradigms that assumed the primacy of relationship. ${ }^{131}$ The foundational

128 Santosky v. Kramer, 455 U.S. 745, 758-59 (1982) (quoting Stanley v. Illinois, 405 U.S. at 651).

129 "A woman needs a man like a fish needs a bicycle." This phrase has been attributed to both Gloria Steinem and Irina Dunn. See Gloria Steinem, Letter to the Editor, Like a Fish Needs a . . . TIME, Oct. 9, 2000, at 20. None of the relational theory analyzed in the forthcoming paragraphs suggests that heterosexual attachment is necessary, only that attachment is necessary. Individuals need to exist in relationship much more than fish need bicycles. Who those relationships are with may not matter that much at all.

130 STEPHEN A. MtTChell, RElational CONCEPTS IN PSychoanalysis: AN INTEGRATION 21 (1988).

131 Object-relations theory, upon which much of the following argument is based, was originally shunned by the American Psychoanalytic Association, but later was incorporated into psychoanalytic thinking. See generally PETER FONAGY, ATTACHMENT THEORY AND PSYCHOANALYSIS (2001). 
work of both Ronald Fairbairn and John Bowlby rested on the notion that one of, if not the, central human motivation is finding and maintaining strong emotional bonds. ${ }^{132}$ Libido, in the words of Fairbairn, is "primarily objectseeking," not pleasure seeking. ${ }^{133}$ Law professor Kenneth Karst puts it in less technical language: "to be human is to need to love and be loved."134 Seeking relationships is a critical part of what human beings do. In turn, those relationships become a critical part of who human beings are.

That the law, particularly constitutional law, has seemed somewhat confused about the importance of relationship is not particularly surprising. Most liberal and social contract theory assumes that human beings are ontologically autonomous. ${ }^{135}$ Isolated individualism is thought to be the primal human state, and the Bill of Rights was arguably drafted to protect people's ability to maintain their distinctive individual identity free from state interference. ${ }^{136}$ From a social contract perspective, people can be legally situated in relationship with others and develop obligations to those others only because those people consented to those relationships and obligations. ${ }^{137}$

At some exceedingly broad level, one can characterize both marriage and parenthood as choices in this way-one consents to be married for better or worse and one assumes the risk of onerous burdens when one becomes a parent-but choice is a remarkably thin way to describe how most people experience their familial obligations. One does not choose to take care of a permanently disabled spouse or choose to love an obstinate, rude and disloyal child; one just does it. It is more instinctive than chosen precisely because one is not just an individual who made commitments that may or may not have been chosen. Instead, one is part of a unit. As George Fletcher

132 MITCHELL, supra note 130, at 22.

133 Ronald Fairbairn, An ObJect-Relations Theory of the Personality 84 (1952); see also id. at 31 ("The ultimate goal of libido is the object ...."). The notion that the human desire for sex is related to the human desire for relationship could have important implications for understanding why and the extent to which the Constitution protects sexual experience. See Ian Ayres \& Katharine K. Baker, A Separate Crime of Reckless Sex, 72 U. CHI. L. REV. 599, 662 (2005) (arguing that when it has protected sexual activity, the Supreme Court has been careful to define that activity as an important element of expression within a relationship, not a protected activity in and of itself).

134 Kenneth L. Karst, The Freedom of Intimate Association, 89 YALE L.J. 624, 632 (1980).

135 For a discussion of how both liberal and critical legal theorists conceptualize the self as ontologically autonomous, see Robin West, Jurisprudence and Gender, 55 U. CHI. L. REV. 1, 12-13 (1988).

136 See NANCY J. HIRSCHMANN, RETHINKING OBLIGATION: A FEMINIST METHOD FOR POLITICAL THEORY 4-6 (1992).

${ }^{137}$ Id. at 5 . 
writes, when it comes to explaining one's primal loyalties, "logic runs dry and one must plant one's loyalty in the simple fact [of belonging]."138

One meets others' needs in family relationships because the interdependence that demarcates family obfuscates one's sense of self. In Fletcher's language "the distance between subject and object" is blurred. 139 Jeffrey Blusetin writes that individuals core attachments "are not merely externally related to their self-conceptions. They are constituents of their identities and ... premises of their agency."140 Karst comments that "our intimate associations are powerful influences over the development of our personalities." 141 Loyalties and duties to the other are not something that one has earned or that one owes or that one chooses to accept, they are a matter of self-interest because the self and the other have become one. ${ }^{142}$

The choice to enter a relationship is thus not just an expression about who one wants to be with, it is a choice that alters who one is. ${ }^{143}$ It is constitutive as well as expressive. ${ }^{144}$ Moreover, as Regan suggests "[s]pouses ... don't simply help each other construct separate individual identities .... [T] hey participate in the creation of a shared [identity]."145 When the law recognizes marriage, the shared identity created by the relationship comes to have a legal status - an autonomy —of its own.

As a matter of doctrine, the Supreme Court has recognized this form of marital autonomy only once, in Griswold v. Connecticut-when it articulated

138 GEORGE FLETCHER, LOYALTY 61 (1993). Here Fletcher is talking about the experience of loyalty generally. When discussing spouses in particular, he suggests that the marital evidentiary privileges essentially operate as privileges against selfincrimination because the distance between the object and the subject becomes so blurred that hurting one's spouse is hurting oneself. $I d$. at 81 .

139 Id. at 61.

140 JEFFREY BLUSTEIN, CARE AND COMMITMENT 251 (1991).

141 Karst, supra note 134, at 636.

$142 \mathrm{See}$ LaUrence D. Houlgate, Family and State 39 (1988) (describing solicitude not as something that he owes his family members but as instinctive obligation); see also MILTON E. REGAN, JR., FAMILY LAW AND THE PURSUIT OF INTIMACY 113 (1993) (one dives into to save a drowning child (or spouse) as much to serve one's own interest as the other's).

143 Or at least it can alter who one is and, for relationships that do work out, it does alter who one is.

144 For more on the constitutive aspects of accepting responsibility, see generally Meir Dan-Cohen, Responsibility and the Boundaries of the Self, 105 HARV. L. REV. 959 (1992) (developing the constitutive responsibility paradigm and suggesting that a person's responsibilities define who a person is).

145 REGAN, JR., supra note 142, at 94. 
a right to marital privacy that allowed married couples to use contraceptives. ${ }^{146}$ In Griswold, the Court famously wrote:

Marriage is a coming together for better or for worse, hopefully enduring, and intimate to the degree of being sacred. It is an association that promotes a way of life, not causes; a harmony in living, not political faiths; a bilateral loyalty, not commercial or social projects. Yet it is an association for as noble a purpose as any involved in our prior decisions. ${ }^{147}$

Seven years later, in Eisenstadt v. Baird ${ }^{148}$ when the Court found that unmarried individuals also had a right to contraceptives, Justice Brennan suggested that marital autonomy might not exist at all: "[T] he marital couple is not an independent entity with a mind and heart of its own, but an association of two individuals each with a separate intellectual and emotional makeup."149

There is very little way to square this individualistic language in Eisenstadt with the notions of unity in Griswold. ${ }^{150}$ Technically, one need not do so because subsequent cases strongly suggest there is an individual right to be free from state interference into reproductive decision-making (a right that would attach to the parties in both Eisenstadt and Griswold). ${ }^{151}$ But if Griswold is nothing more than a case about contraception, it would make no sense to quote it, as the Supreme Court has consistently done, in the later cases having to do with family relationships in general and marriage in particular. ${ }^{152}$ Moreover, there is a long, deep and venerable common law

146381 U.S. 479,485 (1965). In finding a right to marital privacy, the Court relied heavily on cases that afforded privacy to the relationship between parents and children: Pierce v. Soc'y of Sisters, 268 U.S. 510 (1925) (state cannot require children to attend public school if there is an adequate private alternative), and Meyer v. Nebraska 262 U.S. 390 (1923) (state cannot prohibit parents from hiring someone to teach their children a language other than English).

147381 U.S. at 486.

148405 U.S. 438 (1972). Eisenstadt involved state restrictions on the distribution of contraceptives to unmarried people.

$149 \mathrm{Id}$. at 453.

${ }^{150}$ See supra text accompanying note 145.

151 See Planned Parenthood v. Casey, 505 U.S. 833, 851 (1992) ("Our law affords constitutional protection to personal decisions relating to marriage, procreation, contraception, family relationships, child rearing ...."); Planned Parenthood v. Danforth, 428 U.S. 52 (1976) (striking down required spousal notification before abortion decision); Roe v. Wade, 410 U.S. 113 (1973) (restricting the state's ability to prohibit abortion).

152 See Zablocki v. Redhail, 434 U.S. 374, 385 (1978) (right to marry); Smith v. Org. of Foster Families for Equal. \& Reform, 431 U.S. 816, 845 (1977) (involving the 
history of treating the marital unit as an entity, with an autonomy of its own. ${ }^{153}$ Justice Brennan completely ignored this well-established law in suggesting that married people do not constitute a unit. The law has always treated married people as an entity for economic, evidentiary, and other legal purposes. ${ }^{154}$ In Martha Fineman's words, the doctrine "articulate[s] ... what might be characterized as an ethic or ideology of family privacy,"155 which she goes on to re-articulate as autonomy.

The autonomous treatment the law affords relationships enables a universe, or at least a community, that serves as a buffer against the outside world. "[W]hen we come home to our families," writes Laurence Houlgate, "we return to a relationship of intimacy, defined by conditions of mind, not overt action, by trust and devotion instead of formal rights, and duties." 156 The abstract and formalistic relationships that define most peoples' nonfamily life leave us searching for relationships that operate differently. Families provide those relationships by "emphasizing 'shared commitment' rather than rules." 157

In her analysis of Americans' understanding of fairness, Jennifer L. Hochschild observes that norms of distribution and desert vary in different

constitutional rights of foster parents); Moore v. City of E. Cleveland, 431 U.S. 494, 499 (1977) (involving the rights of extended family members to be treated as a family); Stanley v. Illinois, 405 U.S. 645, 651 (1972) (involving the right to paternal status); see also In re Marriage Cases, 49 Cal. Rptr. 3d 675, 715 (Dist. Ct. App. 2006) (right to marry); Goodridge v. Dep't of Pub. Health, 798 N.E.2d 941, 955 (Mass. 2003) (right to marry).

153 McGuire v. McGuire is the most famous case. 59 N.W.2d 336 (Neb. 1953). In McGuire, the Nebraska court refused to find justiciable a wife's claim to a higher living standard even though it was clear that the couple could afford to live more comfortably. Id. at 342 .

154 The legal treatment of the marital relationship has been subject to severe criticism by feminists. See Reva Siegel, "The Rule of Love": Wife Beating as Prerogative and Privacy, 105 YALE L.J. 2117, 2161-70 (1996) (notion of marital unity emerged to bar women from suing their husbands even as the common law evolved to allow married women to sue others in tort and contract). Siegel refers to the ways in which the law maintains traditional coverture principles that rob married women of their rights as individuals as "preservation through transformation." Id. at 2119; see also Katharine Silbaugh, Turning Labor into Love: Housework and the Law, 91 Nw. U. L. REV. 1, (1996) (demonstrating how the law views women's labor as intrinsic to the marital relationship, not as an independent source of entitlement). Part III.B.2 elaborates on the feminist critique of marriage.

155 Martha Albertson Fineman, What Place for Family Privacy?, 67 GEO. WASH. L. REV. 1207, 1214 (1999).

156 HoUlGATE, supra note 142 , at 35 .

${ }^{157}$ Karst, supra note 134, at 639. 
realms. ${ }^{158}$ In the socializing domain (which she describes as family, school, and friends) norms of equality and need predominate. What one is entitled to (love, care, even material goods, sometimes) depends not on what one has accomplished or what one promised, but simply on the fact that one is a member of that domain. Indeed, psychological literature suggests that "promoting an 'exchange orientation' may be inimical to the process of establishing intimacy. It leads people to monitor their partners and keep running accounts in a way that makes momentary violations [too] salient ...."159 It is being in the family, not what one does in the family that determines entitlement, just as it is being in the family, not what one has promised, that determines obligation. ${ }^{160}$ The strength of the familial norms of entitlement explain how family can operate as such a haven. One is entitled because one is of the family. One need not prove anything.

The law honors these alternative norms of entitlement by leaving the families alone while intact and by emphasizing membership not contribution at dissolution. As Fineman writes, the "ideology of state non-intervention is rooted in idealization, but also references the perceived pragmatics of family relationships and the acknowledged limitations of legal... systems as substitutes for family decision-making."161 By refusing to import its own rules, the law encourages parties to work things out on their own, to forge their own sense of purpose as an entity, and to develop norms that facilitate

158 JENNIFER L. HOCHSCHILD, WHAT'S FAIR? AMERICAN BELIEFS ABOUT REDISTRIBUTIVE JUSTICE 47-50 (1981).

159 John G. Holmes \& Susan D. Boon, Developments in the Field of Close Relationships: Creating Foundations for Intervention Strategies, 16 PERSONALITY SOC. PSYCHOL. BULL. 23, 27 (1990) (citation omitted); see also Lenahan O'Connell, An Exploration of Exchange in Three Social Relationships: Kinship, Friendship and the Marketplace, 1 J. OF SOC. \& PERS. RELATIONSHIPS 333, 341-42 (1984) (finding no reciprocity norm in exchanges between kin members and close friends). "Many believe that friendship and kinship bestow a license to request help without imposing any imperative obligation to reciprocate." $I d$. at 341 .

160 The familial norm of entitlement is very different than one's sense of entitlement in more public spheres. Hochschild suggests that inequality norms are acceptable and even preferable in the market domain, where there is an acceptable theory of desert that explains disparity. HOCHSCHILD, supra note 158 , at 49 . Equality is the operative norm in the political realm, but it is not material or emotional goods that are distributed in that realm, it is political rights. To the extent that one asks Americans to view economic rights as political rights, they usually deny or transform the hypothetical. Id. at 48 . Law plays a huge role in constructing the theories of desert in the market domain and in constructing the nature of the participatory rights in the political realm, but it plays much less of a role in the social domain. It defines the social domain and then usually lets distributions within that domain work themselves out, until parties within the domain call on the law to interfere, i.e., at divorce or termination of parental rights.

161 Fineman, supra note 155 , at 1214. 
their lives together. The process of working it out bolsters a sense of intimacy precisely because the abstract and formalistic rules of law have no relevance. There are no universal truths for relationships. ${ }^{162}$

The intimacy and trust of family relationships, an intimacy and trust born from sharing not only day-to-day life, but also the "distinctively personal aspects of one's life"163 create "attachments and commitments"164 that the law honors by making exit difficult and by refusing to interfere in most dayto-day life. ${ }^{165}$ These restrictions are simultaneously taxing and liberating. "Bonds of lasting intimacy leave family members undeniably vulnerable, but the same relationships and loyalties that seem to tie us down are, paradoxically, the sources of strength most likely to lift us up."166

The law's treatment of relationships thus privileges the entity over the individual. Through property rules, ${ }^{167}$ explicit statutes, ${ }^{168}$ and common law duties, ${ }^{169}$ the law sets norms not just for sharing, but for fusing, for making it difficult for individuals to think about their property or their needs as distinct from those of their partners. In setting these norms, the law facilitates the fulfillment what may be core-or at least widely held-human needs to transcend self in the context of relationship.

162 As Hillary Clinton commented at a time when the entire world was looking at her marriage through a microscope and wondering how it could possibly work, "I have learned a long time ago that the only people who count in any marriage are the two that are in it." Maureen Downey, Saturday Talk, ATLANTA J.-ConST., Jan. 31, 1998, at A11.

163 Roberts v. U.S. Jaycees, 468 U.S. 609, 620 (1984).

164 Id. Milton Regan also suggests that trust flows from the intimacy of day to day life. "[Trust] can flow out of the progress of a relationship with another, as daily experience incrementally and almost imperceptibly creates a milieu in which persons come to trust each other ..." MILTON REgAN, JR., ALONE TOGETHER: LAW AND THE MEANINGS OF MARRIAGE 25 (1999).

165 The refusal to interfere (as manifested in the spousal immunity doctrines, the evidentiary privileges and the common law doctrine of non-interference) is a common law, not a constitutional doctrine. See McGuire v. McGuire, 59 N.W.2d, 336, 342 (Neb. 1953). It operates in much the same way as the constitutional doctrine of parental autonomy does though. See infra Part IV.B.1.

166. Bruce C. Hafen, The Family as an Entity, 22 U.C. DAVIS L. REV. 865, 912 (1989).

167 See infra notes $168-70$.

168 See, e.g., N.Y. FAM. CT. ACT $\$ 412$ (Gould 1962) ("A married person is . . chargeable with the support of his or her spouse."); MONT. CODE ANN. § 40-2-102 (2009) ("Insofar as each is able, the husband and wife shall support each other out of their property and labor.").

169 For instance, the necessaries doctrine requires a spouse, if able, to pay for another spouse's "necessaries." See ELLMAN ET AL., supra note 70, at 159-61. 
When legal relationships dissolve and the law does get involved in distributing financial assets, courts do not focus on particular individual contributions or needs, at least if the relationship has been relatively longlasting. For the most part, courts distribute all property earned during the marriage evenly, regardless of who earned it. ${ }^{170}$ With regard to maintenance, the divorce reforms in the 1970s and 1980s endorsed the idea of making maintenance a function of individual need or contribution, ${ }^{171}$ but recent judicial and statutory trends have rejected these reforms as inimical to the idea of marriage and shifted the emphasis to the length of the marriage (the amount of time of belonging), not individual sacrifice or entitlement. ${ }^{172}$ In other words, whatever one contributed or did as a spouse, if one was married for long enough, one is entitled to maintenance. It is the fact of belonging that matters. ${ }^{173}$

\section{Marriage as Oppressive?}

This noble and psychological story about how and why the law respects relationship has thus far (purposefully) neglected to mention how very devastating the traditional treatment of relationship has been for many women, notwithstanding property and maintenance laws designed to protect

170 At divorce, all property earned during the marriage is considered either community property (in community property states) or marital property (in common law jurisdictions). See HARRIS, TeITELBAUM \& CARBONE, supra note 109, at 38-40.

171 See ELLMAN ET AL., supra note 70, at 363-64 (discussing "reforms" in alimony laws), 380-86 (discussing the problems with the rationales that alimony "reform" relied on).

172 See id. at 386: "Marital duration appears to be a critical factor for nearly every court asked to make an award of 'support alimony'-alimony with no definite termination date that is intended to provide the obligee with a more comfortable living standard." See also ALI PRINCIPLES, supra note 35, at $\S 5.04$, Cmt. C:

Despite the conceptual difficulties with the contract and contribution rationales, the cases reflect an enduring intuition that the homemaker in a long-term marriage has some claim on the other spouse's post-divorce income. That intuition does not depend on any assumption that the parties made explicit promises to one another, but on the belief that the relationship itself gives rise to obligations .... The remedy is proportional to the marital duration because the obligations recognized under this section do not arise from the marriage ceremony alone, but develop over time as the parties' lives become entwined.

173 Comparably, child support awards are set pursuant to rigid statutory grids as a way of preventing judges from making individual assessments about children's needs or desires. What a child is entitled to is a function of the fact of her legal relationship to her parent, not a function of her particular situation. See Baker, Bargaining or Biology?, supra note 39 , at $7-8$. 
them somewhat. As Lee Teitelbaum recognized over twenty years ago, "[w]hen courts refuse to resolve ... [intra-family] disputes, that decision is founded on the principle of family autonomy .... . However, the practical consequence of many, if not all, of these decisions is to confer or ratify the power of one family member over others." 174 Despite the reciprocal rights and obligations that the law imposed on husbands and wives, for hundreds of years it was all too clear that the refusal of the law to interfere let a man abandon or ignore his obligations to his spouse, use force against his wife, or both if he thought that, for any reason, she was ignoring her obligations. ${ }^{175}$ Because women had so few options in life outside of marriage, they were completely dependent on the largesse of their husbands within it.

The fact that for centuries marriage has served as an institution that allowed the law to subordinate women's property interests and ignore women's physical and emotional well-being might well auger in favor of constitutional suspicion of marriage, not reification of it. One could easily argue that the equality principles embedded in the Equal Protection Clause require the law to scrutinize the ways in which the law privileges relationships precisely because, as Teitelbaum observed, by privileging relationships the law privileges the more powerful at the expense of the less powerful, and thereby denies the less powerful full voice and participation in society.

Furthermore, the legal recognition of marriage may not be that important to women because they are already more likely to experience life as a web of connections to others. Women may not need marriage because they do not crave intimacy the way men do; ${ }^{176}$ as Robin West writes, "[w]e just do it. It is ridiculously easy." 177 Perhaps, when the Supreme Court has referred to the

174 See Lee E. Teitelbaum, Family History and Family Law, 1985 WIS. L. REV. $1135,1174$.

175 See generally Elizabeth M. Schneider, The Violence of Privacy, 23 CoNN. L. REV. 973 (1991) (analyzing the myriad ways that privacy doctrine has allowed men to control and abuse women in marriage).

176 See Katharine K. Baker, Property Rules Meet Feminist Needs: Respecting Autonomy by Valuing Connection, 59 OHIO ST. L.J. 1523, 1549-58 (1998) (describing how the traditional justifications for the treatment of marriage ignore the substantial feminist literature that suggests that women may crave and need formalism and independence, not altruism and intimacy, because caring and connection seem to come so much more easily to women). Even if this is true, however, women may still support state-sponsored marriage because they recognize that the traditional legal treatment of relationship helps men overcome a more individualistic outlook toward life. Id. at 1595 . "[W]ives may benefit from the extent to which legal protection of marriage encourages their husbands to become more caring, intimate, and selfless." Id.

177 West, supra note 135, at 40 ("Intimacy is not something which women fight to become capable of. We just do it. It is ridiculously easy."). The gendered facility with 
human flourishing that marriage enables, ${ }^{178}$ it has been seeing the world through a distinctly male lens, and whatever values may be served by fostering the intimacy of marriage, those values pale in comparison to the equality concerns that seem antithetical to it.

Reasonable minds may well disagree on this question. The contemporary empirical evidence continues to show that the vast majority of women marry, ${ }^{179}$ even more women express a desire to marry, ${ }^{180}$ and those women who do marry are happier, healthier and wealthier than those who do not. ${ }^{181}$ To be sure, there are endogeneity concerns with this data. Marriage may make people happier, healthier and wealthier, but happy, healthy and wealthy people are probably more likely to marry. ${ }^{182}$ Moreover, state policies and norms supporting marriage help explain why married people would feel happier (they are comporting with a social norm), healthier (they have easier access to health insurance) and wealthier (they get preferable tax

intimacy may explain why, historically, marriage has been more psychologically beneficial to men. See generally STEVEN NOCK, MARRIAGE IN MEN's LIVES (1998).

178 See Griswold v. Connecticut, 381 U.S. 479, 486 (1965).

179 of women over age 15 , only $27.3 \%$ are never married. Of women between the ages of $35-44$, only $16.4 \%$ are never married. See U.S. Census Bureau, S1201: Marital Status, 2006 American Community Survey, available at http://fastfacts.census.gov/ servlet/STTable?_bm=y\&-state=st\&-qr_name=ACS_2006_EST_G00_S1201\&-ds_name $=$ ACS_2006_EST_G00_\&-redoLog $=$ false\&-_caller $=$ geoselect\&-geo_id $=01000 U S \&$-for 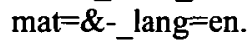

${ }^{180}$ In an online poll of 13 - to $24-y e a r-o l d s, 52 \%$ definitely want to get married and $40 \%$ probably want to get married. Polling the Nations, Marriage (Aug. 20, 2007), http://poll.orspub.com/document.php?id=quest07.out_16101\&type-hitlist\&num=156 (last visited Dec. 16, 2009).

181 Steven Nock writes:

The many beneficial effects of marriage are well-known. Married people are generally healthier; they live longer, earn more, have better mental health and better sex lives, and are happier than their unmarried counterparts.... Some disagreement may exist about the magnitude of such effects, but they are almost certainly the result of marriage, rather than self-selection.

NocK, supra note 177, at 3 (citing numerous studies). For a more recent study, see Alois Stutzer \& Bruno S. Frey, Does Marriage Make People Happy or Do Happy People Get Married?, 35 J. SOC.-ECON. 326, 342 (2006) (finding that marriage continues to be highly correlated with happiness for both men and women and that "[i]t is unlikely that ... selection effects can explain the entire difference in well-being between singles and married people."); see also Goive Marriage, M. Hughes \& C. Style, The Family Life Cycle-Internal Dynamics and Social Research Consequences, 58 SOC. \& SOC. RES. 5668 (1983) (marriage improves women's lives substantially).

182 Depressed, sick, and poor people are not seen as particularly good marital prospects. Nonetheless, the studies cited in the previous note suggest that it is unlikely that the benefits of marriage could be entirely due to selection effects. 
treatment). ${ }^{183}$ Maybe the only reason women want to marry is because they will be considered normal and get access to health care and tax benefits. After all, there are numerous women who cherish their "emotional individualism"184 and flourish both psychologically and materially outside the confines of marriage. Maybe if the state stopped supporting marriage, women would run from it.

Maybe. But at times it seems as if the feminist critique of marriage is running into the same road block that the feminist critique of sexuality did. ${ }^{185}$ For much of the 1980s feminism consistently emphasized how women's subordination was sexualized and how sexualized domination permeated women's lives. ${ }^{186}$ In the words of Catharine MacKinnon, women's sexuality was "defined by men, forced on women, and constitutive of the meaning of gender." 187 In response, numerous women-many of them self-defined feminists-challenged the feminist orthodoxy asking (to paraphrase Kathryn Abrams) "what are we supposed to do about sex while we are fighting for freedom?"188 The numerous women-many of them feminists-who continue to enter into the institution of marriage may be asking a comparable question, "what are we supposed to do about family while we are fighting for freedom?"

Much of the feminist critique of marriage argues that marriage is, as MacKinnon said women's sexuality was, "defined by men, forced on women

\footnotetext{
183 See Bernstein, supra note 8, at 161-63 (and notes cited therein).

184 See Rachel F. Moran, How Second-Wave Feminist Forgot the Single Woman, 33 HOFSTRA L. REV. 223, 228 (2004).

185 For recent contributions to the feminist critique of marriage and legal family, see Laura A. Rosenbury, Friends With Benefits?, 106 MicH. L. REV. 189, 212 (2007) ("Elevating [family] relationships over friendships contributes to gender inequality by encouraging individuals to engage in domestic coupling rooted in a history of patriarchy and then stigmatizing those who live outside of that coupling.") (citations omitted); Dan Markel, Jennifer M. Collins \& Ethan J. Leib, Criminal Justice and the Challenge of Family Ties, 2007 U. ILL. L. REV 1147, 1190 ("[T]he family often served (and in some cases, continue[s] to serve) to perpetuate patriarchy, gender hierarchy, or domestic violence."); see also Nancy Polikoff, We Will Get What We Ask For: Why Legalizing Gay and Lesbian Marriage Will Not "Dismantle the Legal Structure of Gender in Every Marriage," 79 VA. L. REV. 1535, 1536 (1993).

186 Kathryn Abrams, Sex Wars Redux, 95 COLUM. L. REV. 304, 305-10 (1995).

187 Catharine A. Mackinnon, Toward a Feminist Theory of the State 128 (1989).

188 Abrams, supra note 186 , at 311 ("[S]ex radicals argued [that] the subordination of pleasure to a virtually exclusive focus on identifying and preventing danger deprived women of a resource vital to self-understanding and resistance. The sex radicals asked... what women were supposed to do about sex while they were fighting for freedom.").
} 
and constitutive of the meaning of gender." 189 Yet despite what has been a century of feminist criticism of marriage, ${ }^{190}$ there still appears to be something in marriage that many women-including women with a strong commitment to gender equality - value. ${ }^{191}$ Even while conceding that the institution of marriage is deeply infused with patriarchal norms and hidden forms of oppression, most women enter it willingly. It could be that most women are just terribly misguided about how bad marriage will be, or it could be that many women have decided that there is something worthwhile in the marital norms that state and culturally sponsored marriage impart. The analysis above suggests that what women may value is the human flourishing that seems to flow from fusion with another and the nourishment one gets from a defined community that can close its doors to the outside world. ${ }^{192}$

This line of argument would also explain why so many gay men and lesbians want to get married. Some commentators bemoan the elevation of "we" language in contemporary gay discourse, ${ }^{193}$ but there is little doubt that

${ }^{189}$ MacKinnon, supra note 187 , at 128 ; see Rosenbury, supra note 185 , at 219 ("[M]arriage, as shaped by the state, plays a vital role in maintaining gender inequality."); Markel, supra note 185 , at 1193 ("'[B]enefits to the family facilitate the perpetuation of gender hierarchy and domestic violence."); Polikoff, supra note 185, at 1536 (marriage is "the worst of mainstream society" and "an inherently problematic institution").

${ }^{190}$ For early critiques, see Emma Goldman, Marriage and Love, in RED EMMA SPEAKS: AN EMMA GOLDMAN READER 204, 210-11 (Alix Kates Shuman ed., 1996) ("The institution of marriage makes a parasite of woman ... It incapacitates her for life's struggle, annihilates her social consciousness, paralyzes her imagination, and then imposes its gracious protection, which is in reality a snare, a travesty on human character.").

191 Commitment to gender equality is correlated to educational level, as is marriage rate. For the link between commitment to gender equality and education, see generally Richard J. Harris \& Juanita M. Firestone, Changes in Predictors of Gender Role Ideologies Among Women: A Multivariate Analysis, 38 SEX ROLES 239, 240 (1998). For the link between marriage rate and education, see Matthew D. Bramlett \& William D. Mosher, Cohabitation, Marriage, Divorce, and Remarriage in the United States, in VITAL \& Health Statistics, at 4 (Dep't Health and Human Servs. Series 23, No. 22 , 2002), available at http://www.cdc.gov/nchs/data/series/sr_23/sr23_022.pdf ("In addition to race and employment status, other characteristics of individuals that have been found to be related to higher probability of getting married include a higher education and earnings.").

192 As Anne Dailey remarked, "while the closed doors of the home have shielded abuse, isolation and exploitation, they have at the same time nurtured love and commitment." Anne Dailey, Constitutional Privacy and the Just Family, 67 TUL. L. REV. 955, 1020-21 (1993).

${ }^{193}$ See Katherine M. Franke, The Politics of Same-Sex Marriage Politics, 15 COLUM. J. GENDER \& L. 236, 239 (2006) ("the rights-bearing subject of the lesbigay rights movement has now become 'the couple'-a We. It is a domesticated couple, and it 
within the gay community there is a strong endorsement of the "we."194 Committed, interdependent, hard-to-break relationships matter powerfully to people and the law plays a role in making those relationships more committed, interdependent and hard to break. When the law recognizes marital relationships, it fosters and facilitates the formative and constitutive roles that those relationships can play in people's lives.

\section{B. The Law and the Importance of Parental Relationships}

\section{Parenthood as Constitutive}

When the law recognizes parental relationships, it fosters and facilitates the formative and constitutive role that parenthood plays in people's lives also. The justification for the legal treatment of parenthood almost perfectly parallels the justification for the legal treatment of marriage. Parenthood enables people to feel powerful love, to fuse with others and to reconstitute themselves in the context of relationship. Like marriage partners, children are critical sources of love. Adults have children, Jeffrey Bluestein writes "not because [children] will continue the family, or are potential sources of relief and aid, but because they are new bonds of love."195 Like marriage, parenthood requires a relinquishment of self, a fusing of self with other such that a parent's decision to run into a burning building to save her child can hardly be construed as an act of altruism. ${ }^{196}$ It is an act of self-interest.

Being a parent is also a means of reconstructing oneself. ${ }^{197}$ Parenting requires accepting the responsibility that allows one to achieve what Katharine Bartlett refers to as an "ennobled self."198 The ability to construct

is a couple that seeks a particular location within a genealogical kinship grid that sutures the couple to the nation.").

194 See, e.g., JONATHAN RAUCH, GAY MARRIAGE 55-71 (2004); the numerous samesex marriage cases brought by claimants eager to be considered a "we."

195 Jeffrey Blustein, Child Rearing and Family Interests, in HAVING CHILDREN 115, 118 (Onora O'Neill \& William Ruddick eds., 1979).

196 Milton Regan explores this kind of hypothetical, suggesting that a stranger's decision to rescue a drowning child can barely be analyzed on the same terms as a mother's because the mother's "decision" seems so much like an instinctive act of selfpreservation. REGAN, JR., supra note 142, at 113.

197 At a colloquial level every parent understands this. That is why so many parents come to see their lives as having two very distinct phases, pre-children and parental, and those phases are not just about sleep deprivation and the facility with which one changes a diaper or installs a car seat.

198 Katharine T. Bartlett, Re-Expressing Parenthood, 98 YALE L. J. 293, 301 (1988) (citing Nel Noddings, Caring: a Feminine Approach to Ethics and Moral EDUCATION 80 (1984)). 
oneself in this ennobled way, to accept the responsibility for "having, nurturing, and educating one's children[,] is central to our conception of human flourishing."199 As David Richards suggests, "[c]hild-rearing is one of the ways in which many people fulfill and express their deepest values about how life is to be lived." 200

The constitutional parental rights cases, including Meyer v. Nebraska, ${ }^{201}$ Pierce v. Society of Sisters, ${ }^{202}$ Prince v. Massachusetts, ${ }^{203}$ Wisconsin v. Yoder, ${ }^{204}$ and Parham v. J.R., ${ }^{205}$ particularly when coupled with other "parent-like" cases, Moore v. City of East Cleveland, ${ }^{206}$ and Smith v. OFFER, ${ }^{207}$ recognize that parenthood plays a key constitutive role in people's lives. Thus, allowing the state to bar parents from pursuing certain desired educational paths for their children would offend the "relation between individual and state . . . upon which our institutions rest" 208 because restrictions on children almost inevitably operate as restrictions on parents also. An adult must be free to steer a child in the "way he should go." 209 The state cannot "standardize its children" by requiring that they go to public school. ${ }^{210}$ In dissent, in Bowers v. Hardwick, Justice Blackmun wrote that the Constitution protects parenthood because "parenthood alters so dramatically an individual's self-definition." 211 The parent-child relationship serves as a source of independent identity for both parent and child.

${ }^{199}$ Stephen Gilles, On Educating Children: A Parentalist Manifesto, 63 U. CHI. L. REV. 937, 962 (1996).

200 David A. J. Richards, The Individual, The Family, and The Constitution: A Jurisprudential Perspective, 55 N.Y.U. L. REV. 1, 28 (1980).

201 Meyer v. Nebraska, 262 U.S. 390 (1923).

202 Pierce v. Soc'y of Sisters, 268 U.S. 510 (1925).

203 Prince v. Massachusetts, 321 U.S. 158 (1944).

204 Wisconsin v. Yoder, 406 U.S. 205 (1972).

205 Parham v. J.R., 442 U.S. 584 (1979).

206 Moore v. City of E. Cleveland, 431 U.S. 494 (1977).

207 Smith v. Org. of Foster Families for Equal. \& Reform, 431 U.S. 816 (1977).

208 Meyer v. Nebraska, 262 U.S. 390, 402 (1923).

209 Prince v. Massachusetts, 321 U.S. 158, 164-65 (1994) (referring to parent's interest in raising child as "sacred private interests").

210 Pierce v. Soc'y of Sisters, 268 U.S. 510, 535 (1925).

211 Bowers v. Hardwick, 478 U.S. 186, 205 (1985) (Blackmun, J., dissenting) (discussing Moore, 431 U.S. at 500-06). Bowers had to do with a consensual sexual relationship between two adults (in some sense, marriage-like); Moore had to do with a relationship between a grandmother and her grandchild (in some sense parent-like). Again, when the Court writes about why it protects either marriage or parenthood, it tends to conflate the reasons. 
The Court has also made clear that "the importance of the familial relationship, to the individuals involved and to the society, stems from the emotional attachments that derive from the intimacy of daily association, and from the role it plays in "promoting a way of life." 212 "It is through the family that we inculcate and pass down many of our most cherished values, moral and cultural."213 In Prince (a parenthood case), the Court foreshadowed the language in Griswold (a marriage case), referring to the interests at stake in child-rearing as "sacred." 214 That sacredness was made all the more explicit in Wisconsin v. Yoder, which respected parents' rights to withdraw their children from public school at age fourteen because the rights of parents include the right to raise children within the tenets of the Amish religion. ${ }^{215}$ It was impossible to afford the parents religious freedom without affording them parental freedom because the freedom to believe and act in accordance with their religious beliefs, a freedom that we often consider a basic individual right, includes a basic relational right, the right to raise one's children in accordance with those beliefs.

The way the Constitution honors the potential for people to enrich and define themselves through parenthood is by leaving the parental relationship alone. "It is cardinal with us that the custody, care and nurture of the child reside first in the parents, whose primary function and freedom include preparation for obligations the state can neither supply nor hinder.'216 Parents are allowed to structure their relationships with their children as they choose. There are mandatory schooling laws, child labor restrictions, and the outside boundaries of abuse and neglect, but, for the most part, the state steers clear of interfering with the parental relationship. Parents are presumed to act in their children's best interest. ${ }^{217}$ As recently as 1989 , Justice Brennan reaffirmed the soundness of the substantive due process cases that treated the parental relationship as outside of the ambit of state regulation. ${ }^{218}$

212 Smith, 431 U.S. at 844 (quoting Yoder, 406 U.S. at 231-33).

213 Moore v. City of E. Cleveland, 431 U.S. 494, 503- 04 (1977).

214 Prince, 321 U.S. at 165; see also Griswold v. Connecticut, 381 U.S. 479, 486 (1965) (marriage is "intimate to the degree of being sacred").

215406 U.S. 205,219 (1972).

216 Prince, 321 U.S. at 166.

217 Parham v. J.R., 442 U.S. 584, 602-03 (1979).

218 Citing Meyer and Pierce, Justice Brennan wrote, "I think I am safe in saying that no one doubts the wisdom or validity of those decisions." Michael H. v. Gerald D., 491 U.S. 110, 142 (1989) (Brennan, J., dissenting). 
In most of these cases, the Court was not careful to separate out the interests of the parents from the interests of the children,, 19 and in Parham $v$. $J . R$, the Court realized that such an effort was probably pointless. The child's "interest is inextricably linked with the parents' interest in and obligation for the welfare and the health of the child." 220 Child and parent are one for legal purposes. ${ }^{221}$

\section{The Parallels to Marriage}

This explication of the parental rights cases suggests that parenthood and marriage are protected for comparable reasons. Indeed, the parental rights cases, more explicitly than the marriage cases, explain why it is that the law needs to care about relationship rights and obligations at all. The law needs to honor family relationship rights because family relationships provide critical sources of identity. They steer people in directions they would not go but for the relationship.222 They afford people a sense of being "inextricably linked" with another, ${ }^{223}$ and they treat "right, coupled with ... duty"224 as twin elements of legally recognized relationship. Family relationships allow us to share the "intimacy of daily association," 225 which in turn allows us to "pass down many of our most cherished values."226

In his article on marriage, Cass Sunstein writes that when the Court evaluated the constitutional dimensions of marriage it "went off track [and

${ }^{219}$ But see Wisconsin v. Yoder, 406 U.S. 205, 244 (1972) (Douglas, J., dissenting) ("On this important and vital matter of education, I think the children should be entitled to be heard."); see also Woodhouse, supra note 41, at 1827-44 (arguing that the refusal to consider the children's perspectives in Meyer and Pierce reflects a paradigm that inappropriately treats children as property).

220 Parham, 442 U.S. at 600 . The Court acknowledged that "some parents may at times act against the interest of their children ... but [that] is hardly a reason to discard wholesale those pages of human experience that teach that parents generally do act in the child's best interests." Id. at 602-03 (quotation marks omitted).

${ }^{221}$ In Troxel v. Granville, 530 U.S. 57, 69 (2000), the Court backtracked from this position somewhat, finding that grandparents may have a right to visit their grandchildren against the wishes of a parent, if it is in the child's best interest. Courts are still required to operate from a (rebuttable) presumption, however, that parents do act in the best interest of their children.

222 See Prince v. Massachusetts, 321 U.S. 158, 164 (1943) (parents have the right to steer children "in the way [they] should go").

223 Parham, 442 U.S. at 600.

224 Pierce v. Soc'y of Sisters, 268 U.S. 510, 535 (1925).

${ }^{225}$ Smith v. Org. of Foster Families for Equal. and Reform, 431 U.S. 816, 844 (1977).

${ }^{226}$ Moore v. City of E. Cleveland, 431 U.S. 494, 503-04 (1977). 
into the cases involving parenting and procreation] because of the intuitive connection between sexuality and reproduction (protected by substantive due process) and marriage (not easily analyzed in the same terms)."227 To assume that marriage cannot be analyzed in the same terms as parenting and procreation may well be to assume something wrong about the legal treatment of parenting or marriage, however. Marriage, like parenthood, shapes identity. Both marriage and parenthood create sources of loyalty and intimacy that root one in something other than oneself or the state. ${ }^{228}$ In striking down the regulations in Meyer and Pierce, the Court emphasized the important mediating function that families can play as an interim institution between the individual and the state. 229 By citing Meyer and Pierce in Griswold ${ }^{230}$ and Zablocki, ${ }^{231}$ the Court suggested that marriage plays that intermediary role as well.

Comparably, the birth control and abortion cases, decided under substantive due process doctrine, say something about the constitutional import of relationship. The liberty interests served both by allowing people to procreate ${ }^{232}$ and allowing them not to ${ }^{233}$ have everything to do with affording

227 Sunstein, supra note 8, at 2097.

228 Intermediary institutions can be critical sources of identity. See Anne C. Dailey, Federalism and Families, 143 U. PA. L. REV. 1787, 1856 (1995) (discussing the communitarian argument about the "constitutive effect that social affiliations have on the development of human identity"). They can also be critical buffers from the state. As Jean Eshtain writes, "[i]t is no coincidence that all twentieth-century totalitarian orders labored to destroy the family as a locus of identity and meaning apart from the state." JeAN ElshtaIN, The Family and Civic Life, in POWERTRIPS AND OTHER JOURNEYS: ESSAYS IN FEMINISM AS CIVIC DISCOURSE 45, 54 (1990). For more on the importance of intermediary institutions, see Gerald E. Frug, The City as a Legal Concept, 93 HARV. L. REV. 1059, 1088 (1980).

229 The Court in Meyer explained that American values were critically different than those proposed by Plato in the IDEAL COMmONwEALTH. Meyer v. Nebraska, 262 U.S. 390,402 (1923). Plato described a world in which all training of young males was the responsibility of the state. Id. The Court wrote: "Although such measures have been deliberately approved by men of great genius, their ideas touching the relation between individual and State were wholly different from those upon which our institutions rest." Id. In Pierce the Court wrote, "The child is not the mere creature of the State; those who nurture him and direct his destiny have the right, coupled with the high duty, to recognize and prepare him for additional obligation." 268 U.S. at 535 . For more on this, see Dailey, supra note 192, at 958 ("[C]onstitutional protection of the family ought to reflect an understanding of the family's distinct role as a vital intermediate institution serving the communal ends of political life.").

230 Griswold v. Connecticut, 381 U.S. 470, 481 (1965).

231 Zablocki v. Redhail, 434 U.S. 374, 381 (1978).

232 Skinner v. Oklahoma, 316 U.S. 535, 541 (1942) (striking down a state law requiring sterilization of developmentally disabled people). 
people some measure of control over which and what kind of relationships will come to define them. The rights to abortion and birth control are not just about the rights to be free of an unwanted pregnancy, they are about the rights to be free of unwanted relationships. ${ }^{234}$ Those rights are important because of the ways in which relationships, particularly relationships that are understood by the parties and by others to be familial, define who we are. ${ }^{235}$

\section{Summary}

Just as the analogy to marital status helped elucidate what claims to parental status are, so the analogy to parental rights helps elucidate why the law should (or must) recognize marriage-like relationships. The parental rights cases suggest that the legal rights and obligations that accompany parenthood play a formidable role in shaping the relationships that determine who one is. The status of the parental figures in these cases was never in doubt. What was in doubt was the extent to which that status included the right to be treated as legally connected. The parenthood cases suggest that the totality of the legal incidents associated with legally recognized relationships, including claims on the other, obligations to the other, and the right to be considered as a unit, shape people's understanding of who they are. This understanding of why parental relationships are important to parents and

233 See abortion and procreation cases, supra notes 65 and 151.

234 Admittedly, this right is gendered. Women have the right to terminate a potential relationship in a way that men do not and because a mother can effectively prevent a father from relinquishing his paternal relationship. See Baker, Bargaining or Biology?, supra note 39, at 9-10. Men can have parental relationships forced on them. This gendered (and arguably unfair) treatment of relationship in the parental context may have come from the recognition that for years men just walked away from parental relationships without much fear of ever being dragged back into them, legally or emotionally.

235 To suggest that the constitutional treatment of marriage has nothing to do with these other treatments of relationship may be to suggest that marriage is some lesser form of relationship than parenthood, arguably either because the marital relation is somehow a legal construct in the way that other family relationships are not, or because parental relationships are simply more important to people than marital ones. Both of those assumptions are misguided. The law has always defined parental status pursuant to a set of criteria that it set, sometimes involving biology and sometimes not. See supra notes 92-97 and text accompanying. Parenthood, particularly fatherhood, is no more pre-legal than is marriage. Moreover, marriage appears to be just as, if not a more, important as parenthood in helping men define themselves in the world. See NocK, supra note 177, passim. If the relation of parent to child is worthy of constitutional protection because of the way in which that relation shapes our identity, then the relation of spouse to spouse may well be also. 
children finds support in the psychological and philosophical theories of adult relationships and family.

\section{CONSTITUTIONAL CONFUSION}

\section{A. Confused Nomenclature}

Part of the reason the connection between marriage and parenthood has not been made more clearly may stem from the imprecise and somewhat circular language the Court has used to protect family relationships. Three related and overlapping terms are often used: intimacy, privacy and autonomy. When speaking about family relationships, the Supreme Court has used the word intimacy frequently, ${ }^{236}$ though it has never articulated a right to emotional or physical intimacy. Instead, there is (maybe) a right to privacy and there are doctrines of family and parental autonomy. Scholars of the Court and of these concepts suggest that the terms all have something to do with each other.

In his famous article on privacy and autonomy, published just after Roe v. Wade, Louis Henkin argued that when the Supreme Court used the word privacy it really meant autonomy, or the right to be free from governmental regulation. $^{237}$ In her famous article on privacy, Ruth Gavison argued that there are actually two kinds of privacy, the right to self-determination (often thought of as autonomy) and the right not to have facts about oneself known. In his article on intimate associations, Kenneth Karst argued that this latter right, the right not to have facts disclosed, is also part of our understanding of what constitutes intimacy. ${ }^{238}$ The other understanding of intimacy involves "close and enduring association between people"239 or relationships. Meanwhile, Jennifer Nedelsky argues that the term autonomy has no meaning outside the context of relationship. "If we ask ourselves what actually enables people to be autonomous, the answer is not isolation, but relationships." 240 Thus, a right to privacy may be a right to autonomy, which has no meaning outside the context of relationship.

236 Griswold v. Connecticut, 381 U.S. 470, 486 (1965) (in the context of marriage); Smith v. Org. of Foster Families for Equal. \& Reform, 431 U.S. 816, 843-44 (1977) (in the context of parental-type relationships).

237 Louis Henkin, Privacy and Autonomy, 74 ColuM. L. Rev. 1410, 1415 (1974).

238 "The first meaning of intimacy is synonymous with one of the meanings of privacy: an intimate fact is a private fact, the sort of information about a person that is not normally disclosed." Karst, supra note 134, at 634.

239 Id.

240 Jennifer Nedelsky, Reconceiving Autonomy: Sources, Thoughts and Possibilities, 1 YALE J.L. \& FEMINISM 7, 12 (1989). 
Diagrammatically, the etymology looks something like this:

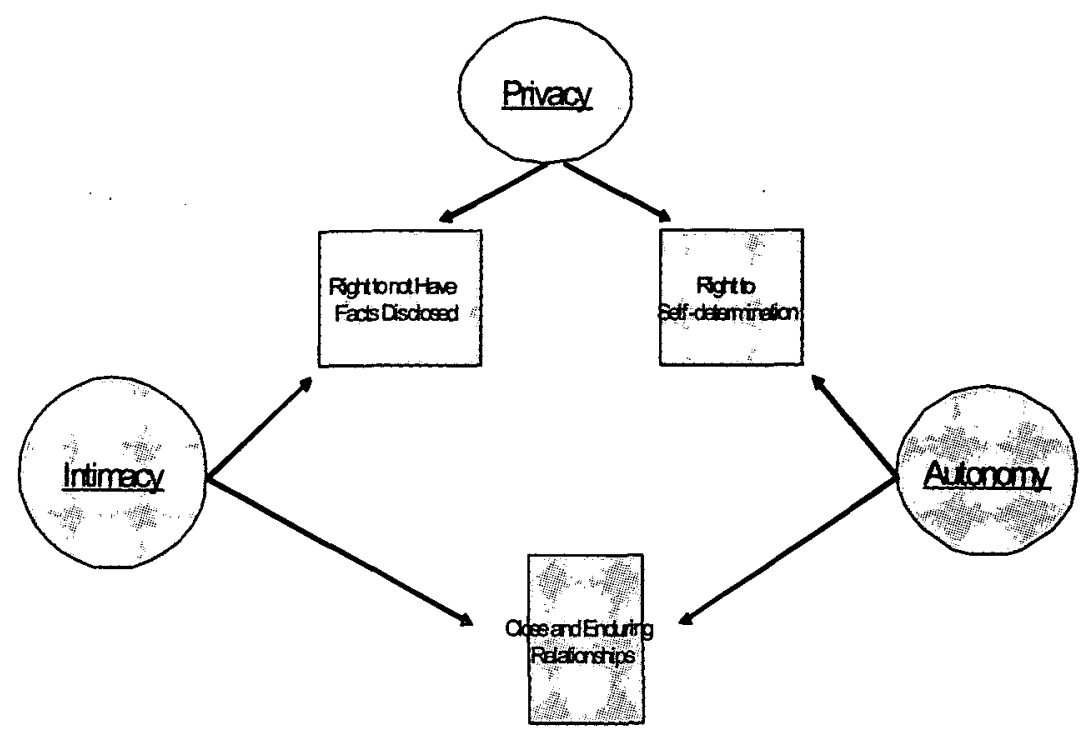

This etymological overlap helps explain some of the doctrinal confusion with regard to relationships. Sometimes that which is protected when we protect relational privacy is the right not to have things disclosed, ${ }^{241}$ but sometimes it is the right to self-determination. ${ }^{242}$ Sometimes, by autonomy, we mean the right to be free from governmental regulation, ${ }^{243}$ but sometimes we mean the right to be treated as intertwined with others. 244 What makes intimate relationships special is that they are both private and autonomous. The people in them exclude the rest of the world, but include each other in a way that makes them both independent and interdependent. When the Supreme Court recognizes the importance of relationship, it is

241 The communication privilege is the most obvious example, but so is the kind of privacy the Court seemed eager to protect in Griswold - the right not to have the government snooping around one's bedroom.

242 The right not to be a parent protected in Roe can be viewed as a right to selfdetermination as can the right of Mr. Redhail to reconstitute himself in the context of relationship. In both contexts, the Court used the word privacy to describe what it was protecting. See Zablocki v. Redhail, 434 U.S. 374, 384 (1978); Roe v. Wade, 410 U.S. $113,152-53$ (1973).

243 The Court in Prince referenced parental "freedom" to raise their children as they wanted, and the Court in Loving spoke of the "freedom" of choice to marry. Prince v. Massachusetts, 312 U.S. 158, 166 (1943); Loving v. Virginia, 388 U.S. 1, 12 (1967).

244 Meyer, Pierce, Prince, and Parham all suggest that part of what parental autonomy means is the right to have the state view the parent-child relationship as an entity, instead of treating parents and children as separate. 
acknowledging the critical role that relationship can play in our lives and it is acknowledging the importance of treating relationships as entities unto themselves.

\section{B. A Due Process Requirement?}

Given the primary role that legally recognized family relationships play and have always played in people's lives, there is a strong argument that the Constitution must recognize family rights in some way. In his article on the constitutional dimensions of tort law, Professor John Goldberg argues that the Constitution requires the state to provide "bodies of law that fit certain descriptions, including laws of ownership, familial relations and enforceable agreements, as well as law for the redress of wrongs." 245 Professor Goldberg rests much of his argument on the historical role that the government has played in the redress of private wrongs, ${ }^{246}$ but his arguments from history work just as well in family relations as they do in tort. Indeed, the Court has relied heavily on history to explain why it feels compelled to protect the family, despite there being no mention of the family in the Constitution. "The fact that no particular provision of the Constitution explicitly forbids the State from disrupting the traditional relation of the family-a relation as old and as fundamental as our entire civilization - surely does not show that the Government was meant to have the power to do so."247 "Our decisions establish that the Constitution protects the sanctity of the family because the institution of the family is deeply rooted in this Nation's history and tradition."248

Just as government has always provided some redress for private wrongs and therefore might be compelled to continue to provide some floor of redress, so the government has always recognized some family rights and obligations and therefore may be compelled to continue to do so. Exactly what the floor is, as Goldberg suggests, will be a function of a variety of factors, including contemporary understandings of (in the tort context) wrongs and (in the relationship context) family. ${ }^{249}$ Thus, Goldberg finds no

245 John C.P. Goldberg, The Constitutional Status of Tort Law, 115 YALE L.J. 524, 594-95 (2005) (emphasis added).

246 Steven Heyman has also argued that history strongly supports a constitutional requirement that the state provide a bare minimum of protection from private wrongs. See Steven J. Heyman, The First Duty of Government: Protection, Liberty and the Fourteenth Amendment, 41 DUKE L.J. 507, 512-30 (1992).

247 Griswold v. Connecticut, 381 U.S. 479, 496 (1965) (Goldberg, J., concurring).

248 Moore v. City of E. Cleveland, 431 U.S. 494, 503 (1977).

249 For the list of factors Professor Goldberg would use to determine the floor, see Goldberg, supra note 245 , at 613. 
problem in the elimination of the torts of seduction or alienation of the affections because evolving understandings of women's rights and women's agency coupled with women's ability to sue in their own right rendered questionable whether the "wrongs" originally meant to be addressed were still considered wrongs. ${ }^{250}$

Comparably, the current tendency to recognize marital and parental rights even if not legal status as spouse or parent suggests that contemporary understandings of legally relevant relationships have progressed some. The state supreme courts in California, Vermont and New Jersey found themselves constitutionally obliged to grant the rights and obligations of marriage even though they did not feel compelled to grant marriage to gay men and lesbians. ${ }^{251}$ Courts and legislatures often feel compelled to grant parental rights even if not the status of parenthood. ${ }^{252}$

When someone who has lived with, cared for, shared with and provided for a partner for years on end presents him or herself to a court, arguing for the right to be recognized as a legally relevant person in that partner's life, the "relation between individual and State... upon which our institutions rest" 253 may require the state to acknowledge the legitimacy of that relationship. When someone who has lived with, cared for, shared with and provided for a child presents him or herself to a court, pleading for the right to be recognized as a legally relevant person in that child's life, a court may be compelled to recognize a liberty interest in "the emotional attachments that derive from the intimacy of daily association." 254 The floor for staterecognized relationship rights may be shifting up.

Goldberg is careful to point out that his notion of due process does not treat "as natural or neutral a set of baselines for constitutional analysis arbitrarily drawn from the common law."255 Instead, he is suggesting that scholars should "self-consciously theorize a connection between private and public law."256 The tension between the lofty constitutional discourse protecting family status, on the one hand, and the statutory or common law

${ }^{250}$ Id. (the conversion of the husband's property interest in his wife's body, or the disnuption of the marital relation no longer seemed like wrongs.)

251 See discussion of Baker v. Vermont and Lewis v. Harris, supra notes 25-27 and text accompanying.

252 See supra text accompanying notes $13,42-47$.

253 Meyer v. Nebraska, 262 U.S. 390, 402 (1923).

254 Smith v. Org. of Foster Families for Equal. \& Reform, 431 U.S. 816, 844 (1977). In Smith, the majority assumed without deciding that foster parents developed a protected liberty interest as parents by living with, providing for and loving their foster children, even if they never asked for legal status as parents. Id. at 843 .

255 Goldberg, supra note 245 , at 625 .

256 Id. 
incidents of legal relationship, on the other, cries out for such a unifying theory in the family law context. As Goldberg notes, "there is a long tradition of holistic thinking in Anglo-American constitutional law, one that treats private law not as sub- or non-constitutional, but as a part of an overall constitutional order."257 Understanding the constitutional protection of relationship as incorporating many of the state laws that treat two as one, in ways that both expand and restrict autonomy, follows that tradition of holistic thinking.

\section{Summary}

Though often confused by its own overlapping rhetoric, the Supreme Court has consistently recognized that significant autonomy, privacy and intimacy values are implicated by the legal treatment of family relationship. The law has always facilitated and helped sustain family relationships by treating them as distinct and free to flourish (or not) pursuant to their own rules, but governed, if at an end, by notions of fusing and sharing. Given how critical these relationships are to peoples' lives and how strong a role the law has always played in protecting them, courts and legislatures seem to sense some affirmative obligation to recognize family-like relationships. The current trend to provide the rights of relationship to non-traditional family members, even while resisting the expansion of traditional notions of family status, may reflect a sense of this affirmative duty.

\section{CONSEQUENCES}

Regardless of whether one thinks states must provide some minimal rubric of relationship rights, and regardless of whether one thinks the current tendency to disaggregate relationship rights from family status provides adequate redress to those who fail to secure family status, it is not clear that the tendency to disaggregate marital and parental rights from their corresponding statuses is a good idea for those who care about the legal protection of relationships. Disaggregation undermines the social meaning of both marriage and parenthood. It also tends to minimize the importance of family obligation and thus makes legally recognized relationship less formative. Finally, disaggregation makes it much less likely that courts will continue to honor the doctrine of family autonomy. This Part explores these likely consequences of disaggregation. 


\section{A. Diminution in Meaning}

As the traditional incidents of marriage and parenthood are increasingly disaggregated from the statuses with which they are associated, the social meaning of the statuses themselves is diffused. It is harder to know what both marriage and parenthood mean in a world in which many who do not have the status are treated as if they do. The Supreme Court of New Jersey recognized this irony when it denied same-sex couples the right to the status of marriage in part because it had granted them the incidents of marriage: "plaintiffs' claimed right to the name of marriage is surely not the same now that equal rights and benefits must be conferred on committed same-sex couples."258 The court thus explicitly acknowledged that the marital label loses some of its importance if people can acquire rights without the label.

In addition to the status losing potence when the rights with which it is associated can be dissociated from the label, the social norms that inform the status' meaning (and are a key part of its stability) may be undermined by the existence of alternative legally recognized relationships. As Elizabeth Scott writes, "the intricate web of social norms regulating spousal behavior contribute[s] to the stability of marriage."259 Marriage alternatives may not incorporate those social norms and it is not clear that marriage can retain them in the face of alternatives. If states develop many ways of viewing partners as in relationship with each other, there will be less reason for people to "know immediately" what the relationship means because it will be harder to internalize which social norms apply to which relationships.

Perhaps the social norms that we now associate with marriage will continue to attach to those who marry even if there are alternative relationships available, but alternative statuses will likely have a weaker norm network supporting them. ${ }^{260}$ This will affect not only the people in those alternative statuses, but people in marriages as well. If people who are in domestic partnerships feel less bound by norms of stability and fidelity and if a married person knows many people in domestic partnerships, the married person's allegiance to those traditional marital norms may seem far less obligatory. 261

258 Lewis v. Harris, 908 A.2d 196, 221 (N.J. 2006).

259 Elizabeth S. Scott, A World Without Marriage, 41 FAM. L.Q. 537, 562 (2007).

260 It is likely that any norms accompanying civil unions or domestic partnerships will be weaker than norms accompanying marriage simply because those statuses are new and people have not had time to internalize the norms associated with them.

261 It could cut the other way. Married people might feel more bound by traditional marital norms precisely because there were alternatives available and they chose marriage. I am not contending that the availability of alternatives will necessarily erode the social norms associated with marriage. I am only contending that it may. 
If marriage does come to seem less important, as the New Jersey Supreme Court suggests that it will once alternative partnership paradigms are recognized, and if marital norms lose more of their strength, as may happen with alternative paradigms providing what will likely be weaker norms, then there is every reason to believe that the proliferation of alternatives to marriage, even though created in the name of preserving marriage, will ultimately undermine the institution. At a minimum, it will make claims to marital status seem more frivolous because it will be less clear that those who are deprived of marriage are deprived of anything significant.

Creating alternative legal forms of parent-like relationships will likely have a comparable effect. It is already clear that creating alternative forms of parenthood dilutes the parental rights of those who are otherwise parents. Here, it is important to underscore a key difference between marriage and parenthood. Expanding the kinds of marital-like relationships available does not alter the legal rights and obligations associated with marriage. ${ }^{262}$ The rights and obligations of different unions may vary depending on whether they are marriages or civil unions or domestic partnerships and, as just discussed, the social meaning and social norms associated with those unions may vary, but if $A$ is married to $B$ and $C$ is domestic partnered with $D, A$ 's legal rights and obligations vis-à-vis $B$ will not be affected by $C$ 's legal rights and obligations vis-à-vis D. ${ }^{263}$ Parenthood is more complicated legally. If $\mathrm{A}$ and $B$ are parents of $C$, and D is a de facto Parent of C, then D's semiparental status undermines the legal rights and obligations of $\mathrm{A}$ and $\mathrm{B}$. The more of a privilege that $D$ has to exercise visitation or custodial rights, the less exclusive are A and B's rights as parents.

If, as may well be the case, ${ }^{264}$ we are moving toward a world in which it is far more common for more than one or two people to have relationship claims to a child, then it is likely that the social meaning of parenthood will diminish in importance. If, for instance, it is relatively common for a child to have a de facto parent in addition to one or two "regular" parents, then it is unlikely that claims for parental status per se will have much resonance. Why should someone like Michael $\mathrm{H}$. be awarded the status of father if it is

262 This assumes a world without polygamy. A world with multiple marriage partners would present the same problems as the kinds of issues we currently have with multiple parenthood. For a thoughtful discussion suggesting that maybe we should not automatically take polygamy off the table, see Elizabeth Emens, Monogamy's Law: Compulsory Monogamy and Polyamorous Existence, 29 N.Y.U. REV. L. \& SOC. CHANGE 277 (2004).

263 As just suggested, the social norms associated with A's partnership with B may affect the social norms associated with C's marriage to D.

264 See Baker, Bionormativity, supra note 38; Bartlett, supra note 41. 
commonplace for people like him to get visitation rights without having parental status? Misters Quilloin and Lehr ${ }^{265}$ would not need to block the adoption of their biological child by another man; they could just assume third party rights. Or the mother's new husband could. In other words, just as the proliferation of many legal forms of partnerships may make claims to marriage itself seem frivolous, so the proliferation of many forms of quasiparenthood may make claims to parental status per se seem frivolous.

\section{B. Diminution in Burden, Diminution in Benefit}

As detailed above, the often harsh and restrictive obligations that the law imposes on marital partners and parents makes sense in light of the ways in which people are enriched and ennobled when the law treats two as one. In crafting the legal rules that require sharing and assume fusing, the law helps people transcend self through relationship. It is because the desire to transcend self in this way is so primary and constitutive that the government may have an obligation to recognize family rights and obligations.

When separating the incidents of status from the statuses themselves, however, courts and legislatures have demonstrated a clear preference for bestowing the benefits of relationship, while not necessarily imposing relational obligations. In the domestic partnership area, employers and legislators are much more likely to allow partners access to third party benefits (health and disability insurance) than to require domestic partners to share property or assume long-term financial responsibility for each other. ${ }^{266}$ In the parental area, courts and legislators are clearly more comfortable awarding visitation than imposing child support obligations. ${ }^{267}$

Creating these "marriage-lite"268 and "parenthood-lite" arrangements ignores the important psychological and constitutive benefits that come from obligation. The legal rules that make family members responsible for one

265 See supra text accompanying notes 100-03.

266 See Blumberg, supra note 14, at 1290-92 (noting how by failing to treat domestic partnership pension rights the way it treats marital pension rights, the UCLA domestic partnership program gives domestic partner's less of a claim on each other's financial assets); see also RAUCH, supra note 194, at 43-46 (referring to domestic partnership as "marriage-lite" and suggesting that such arrangements often don't include all of the obligations of marriage).

267 Compare, e.g., E.N.O. v. L.M.M., 711 N.E. 2d 886, 892 (Mass. 1999) (awarding visitation rights to a non-biological lesbian co-partner in part because of pre-existing agreement to share parenting), with T.F. v. B.L., 813 N.E. 2d 1244, 1246 (Mass. 2004) (ruling that a pre-existing agreement in which the non-biologically related lesbian partner agreed to provide support for the child was not binding). See generally Baker, supra note 43 , at 121 .

268 See RAUCH, supra note 194, at 31. 
another help define our social understanding of family obligation. That social understanding in turn informs our conceptualization of family and, most likely, our personal interpretations of connection and obligation. How fused does one feel with someone else if there is no mutual long term obligation to support? How much can a parental relationship change who one is if one is not legally required to do anything for or with the child?

To some, state-imposed family obligations may seem superfluous because the duty to care derives from emotional, not legal, obligations. Yet millions of ex-spouses try to minimize post-divorce support, just as millions of parents try to dodge child-support obligations. Would marriage and parenthood carry with them the same personal or social meaning if their legal meaning changed such that the law let people walk away from the family obligations they had once accepted? Without the traditional obligations of spouse and parent, the roles of partner and caretaker become much less formative and meaningful and therefore less worthy of constitutional protection. Over time, if more people in legally recognized relationships fail to live up to the traditional obligations associated with those relationships (because the law does not make them) then the need to honor any nontraditional relationship may decline because those relationships will be seen as more voluntary and less constitutive.

\section{Diminution in Privacy}

Finally, the less uniform the social meaning of marriage and parenthood, the less likely that the law will protect the negative rights and the ideology of privacy associated with family statuses. The Supreme Court of California emphasized the importance of family privacy in In re Marriage Cases. "One very important aspect of the substantive protection afforded by the ... constitutional right to marry is, of course, an individual's right to be free from undue government intrusion (or interference with) ... the right to marital or familial privacy."269 Yet the more legally varied and individualized family-like relationships become, the less likely courts will be to respect family privacy because courts will need to insert themselves inside those families, in order to ascertain the individual rights and responsibilities involved.

For instance, domestic partners who have access to each other's health insurance and rights to hospital visitation, but who do not live in states that treat domestic partners as married for financial purposes, will be left to rely

${ }^{269}$ In re Marriage Cases, 183 P.3d 384, 426 (Cal. 2008). The court went on to say "the constitutional right to marry ... obligate[s] the state to ... protect the core elements of the family relationship from at least some types of improper interference by others." Id. at 426-27. 
on notions of constructive trust, quasi-contract or contract for adjudication of questions pertaining to property distribution and future financial support. Not only do these theories often fail to render just or consistent results, 270 they involve searching inquiries into what actually happened during the course of the relationship. In order to prove a constructive trust that can secure for one an interest in an ex-partner's property, plaintiffs must demonstrate the extent of their individual contributions to the relationship. ${ }^{271}$

Comparably, plaintiffs using claims of implicit contract must parade the details of their relationship before the court in order to establish the agreement pursuant to which they expect to collect. ${ }^{272}$ Even with this evidence, courts often resist finding implicit contracts. As the New York Court of Appeals wrote in Morone v. Morone:

As a matter of human experience personal services will frequently be rendered by two people living together because they value each other's company or because they find it a convenient or rewarding thing to do. For courts to attempt through hindsight to sort out the intentions of the parties and affix jural significance to conduct carried out within an essentially private and generally noncontractual relationship runs too great a risk of error. 273

Morone thus required that plaintiffs show an express contract before they can collect on any promise for future support.

270 See generally Ira Mark Ellman, “Contract Thinking" Was Marvin's Fatal Flaw, 76 NOTRE DAME L. REV. 1365 (2001) (discussing the failure of contract doctrine to incorporate the variety of factors that should go into a spousal compensation award).

${ }^{271}$ See, e.g., Sullivan v. Rooney, 533 N.E.2d 1372, 1374 (Mass. 1989) (evidence plaintiff gave up job as flight attendant and maintained home for defendant helped establish a constructive trust on the home purchased by her ex-partner); Evans v. Wall, 542 So. 2d 1055, 1056-57 (Fla. Dist. Ct. App. 1989) (evidence of plaintiff's contributions of food, telephone service, furnishings, cooking, washing and cleaning services used to establish a constructive trust that would allow her to receive a share of her ex-partner's property); Small v. Harper, 638 S.W.2d 24, 28 (Tex. Ct. App. 1982) (constructive trust is the appropriate doctrine under which to evaluate female cohabitant's claim to her ex-partner's property); Minors v. Tyler, 137 Misc. 505, 508 (N.Y. City Civ. Ct. 1987) (same, with genders reversed).

272 See Watts v. Watts, 448 N.W.2d 292, 296-97 (Wis. Ct. App. 1989) (court evaluating extensive evidence of parties' behavior and finances); Glasgo v. Glasgo, 410 N.E.2d 1325, 1331 (Ind. Ct. App. 1980) (recovery for parties seeking relief "[sh]ould be based only upon legally viable contractual and/or equitable grounds which the parties could establish according to their own particular circumstances") (emphasis added); see also Bright v. Kuehl, 650 N.E.2d 31 1, 315 (Ind. Ct. App. 1995) (following Glasgo).

${ }^{273}$ Morone v. Morone, 413 N.E.2d 1154, 1157 (N.Y. 1980). 
Express contract theories prove to be just as intrusive, however, because prohibitions on contracts for sexual services mean that courts take the consideration inquiry very seriously. Thus, in two different cases involving express contract, California courts found consideration when an ex-partner served as chauffeur, bodyguard and social and business secretary, ${ }^{274}$ but not when another ex-partner served only as social companion and hostess. ${ }^{275}$ New York courts have found that foregoing a career opportunity for the sake of a relationship is adequate consideration, ${ }^{276}$ but they will not presume that an unemployed ex-partner forewent career opportunities. ${ }^{277}$

It is precisely these kinds of detailed particularities of different relationships that courts have traditionally eschewed in the name of allowing family relationships to construct themselves on their own. The parties to a marriage get to determine what is fair and reciprocal and courts accept that determination as such to the extent that they are bound to divide the property in half, regardless of the roles taken in producing it. As discussed, legal obligations and liabilities have attached because of the fact of family status and regardless of the particular details of individual family arrangements. The more courts get into the details of relationships without that status, the less allegiance they may feel to the ideology of family autonomy in general.

Comparably, a child who has legally cognizable relationships with numerous adults is a child who is much more likely to have his schooling decisions, religious upbringing and extracurricular activities determined by a judge than by one or two parents. As of now, adults with parental status have an almost irrebuttable right to visitation and guaranteed standing to assert a claim for custody. ${ }^{278}$ If parents are married, their decisions regarding their children are presumed to be in their children's best interest. The quality and content of their relationships with their children is never at issue.

274 Whorton v. Dillingham, 248 Cal. Rptr. 405, 409 (Dist. Ct. App. 1988).

275 Bergen v. Wood, 18 Cal. Rptr. 2d 75, 77 (Dist. Ct. App. 1993). Curiously, the court refused to find consideration here because the parties never cohabited. Id. Thus, apparently, cohabitation is an essential part of the consideration necessary for a support promise, even though sexual services alone are an impermissible basis for consideration.

276 McCullon v. McCullon, 410 N.Y.S.2d 226, 233 (N.Y. Sup. Ct. 1978).

277 Cohn v. Levy, 725 N.Y.S.2d 376, 377 (N.Y. App. Div. 2001). The court emphasized that the plaintiff had not held a job in some time. She had been previously married, but the court did not explain how it thought she would have provided for herself if she had not been in the relationship. Presumably, she had to have foregone whatever other means of support would have kept her provided for, but the court did not acknowledge this.

278 "Denial of visitation is an extreme remedy, rarely approved." HARRIS, TEITELBAUM \& CARBONE, supra note 109, at 103. 
But if a third party has potential rights, the behavior of both the adults with parental status and those without it comes under scrutiny. In order to determine whether a third party non-parent has standing to make a visitation or custody claim, courts insist on analyzing "the nature of [the] parent and child relationship."279 "[W]hile it is presumed that a child's best interest is served by maintaining the family's privacy and autonomy, that presumption must give way where the child has established strong psychological bonds with a [a non-legal parent]."280

It is already clear that in cases of divorce, courts evaluate religious practices, ${ }^{281}$ choice of community decisions, ${ }^{282}$ and financial entitlements. ${ }^{283}$ For married parents, the ability of parents to make these difficult, value-laden child rearing decisions is what makes parenthood "central to our conception of human flourishing."284 Yet the more people there are with rights to rear one particular child, the less able any of them are to "inculcate and pass down [their] most cherished values." 285 The more adults with relationship rights to a child, the more potential legal disputes there are and the more likely it is that a court, not a parent, will be determining what is in the child's best interest. The constitutive benefits of parenthood, and the privacy of all parents involved, will be seriously compromised.

\section{CONCLUSION}

There is an extensive academic critique of the family suggesting that perhaps the law should just get out of the family relationship business altogether. ${ }^{286}$ Despite this critique, many, many people continue to ask the

279 Mason v. Dwinnell, 660 S.E.2d 58, 65 (N.C. Ct. App. 2008).

280 T.B. v. L.R.M., 786 A.2d 913, 917 (Pa. 2001) (quoting J.A.L. v. E.P.H., 682 A.2d 1314, 1319-20 (Pa. 1996)).

281 In re Hadeen, 619 P.2d 374 (Wash. 1980); Mentry v. Mentry, 190 Cal. Rptr. 843, 850 (Dist. Ct. App. 1983).

282 In re Marriage of Sheley, 895 P.2d 850, 856 (Wash. Ct. App. 1995) (custodial mother could not move out of Seattle area); Ramirez-Barker v. Barker, 418 S.E.2d 675, 680 (N.C. Ct. App 1992) (holding that primary custodian could not move in order to be closer to relatives).

283 If family income is over a certain amount, courts determine the "realistic needs of the children." Peterson v. Peterson, 434 N.W.2d 732, 738 (S.D. 1989); see also In re Marriage of Bush, 547 N.E.2d 590, 596 (Ill. App. Ct. 1989).

284 See Gilles, supra note 199, at 962.

285 See Moore v. City of E. Cleveland, 431 U.S. 494, 503-04 (1977).

286 More commentators seem eager to dispense with marriage than parenthood. See, e.g., Martha A. Fineman, The Meaning of Marriage, in MARRIAGE Proposals: QUESTIONING A Legal STATUS (A. Bernstein, ed. 2006) (advocating eliminating 
law to recognize their family relationships. Marriage and parenthood, partnership and caretaking may look very different today than they did fifty years ago, but for the most part, people are not rejecting any role for the law in shaping and defining family relationships, they are asking the law to draw family shapes and make family definitions that include them.

To the extent that litigants have made constitutional claims to be included in traditional definitions of family, they have not been that successful. Constitutions do not afford particularly robust protection to family status. Claimants have been much more successful in securing relationship rights, however. Sometimes these rights are granted, under state constitutions, in lieu of conferring traditional status; sometimes these rights are granted legislatively; sometimes courts simply create doctrines that recognize relationship rights and obligations between non-traditional family members.

The prevalence of this legal recognition of non-traditional relationships suggests that legal actors appreciate the state's affirmative duty to recognize relationship rights. Courts and legislatures feel compelled to honor certain relationships legally even if they don't feel compelled to afford those relationships family status. When looked at as a whole, the Supreme Court doctrine on relationships suggests that there is some constitutional requirement that the law respect family relationships for reasons other than just their expressive potential, for reasons that have to do with the formative role that family relationships play in many people's lives.

If one believes that the law's role in fostering and promoting these relationships is beneficial and important, though, this Article suggests that courts and legislatures should be wary of disaggregating relationship rights from relationship status in the way that they have. While jealously guarding what it means to be married and what it means to be a parent, courts and legislatures have created an alternative regime of relationship rights that ultimately may undermine some of the most important ways that the law honors relationships. Cafeteria-style family rights require a degree of judicial construction, monitoring and evaluation that is antithetical to the privacy,

marriage, but strengthening parenthood); Polikoff, supra note 185 (arguing that marriage is irredeemably gendered); Sunstein, supra note 8, at 2104 (questioning the benefits of marriage while assuming that the law's treatment of parenthood is appropriate). Few people argue for dispensing with the idea of parenthood, but several argue for opening the category up significantly. See Bartlett, supra note 41 (arguing that adults who have played significant roles in children's lives should be given legal rights); Woodhouse, supra note 41 (arguing to provide parental rights to adults who have supported a mother during pregnancy). I have suggested that perhaps we should restrict our notion of parenthood, at least in infancy, so as to minimize the role of biology. See Baker, Bargaining or Biology?, supra note 39 , at $45-48$. 
intimacy and autonomy values that motivate the law to respect relationship in the first place.

Concretely, what this means is that if one believes in the legitimacy and importance of legal marriage, then one should be wary of supporting "marriage-lite" arrangements because the very existence of alternative structures will foster a legal culture that is used to inserting itself inside relationships to define and evaluate them, instead of leaving them alone. Comparably, if one believes in the importance of parental autonomy and privacy, one needs to be wary of alternative parenting constructs that give courts not only the discretion, but often the duty, to make traditional parenting decisions.

Conservatives and (some) liberals can even agree on the analysis to this point. They can agree that the disaggregation of rights from status is dangerous. Where they will part ways is in what to do about it. To conservatives, the response to the danger will be to try to reign in the liberal social norms and values that have allowed alternative family forms to flourish. If alternative family forms cease to exist in such numbers, the pressure on the law to recognize them will obviously dissipate.

To liberals who believe that many non-traditional relationships should be recognized by law, the response to the danger will be to try to fight all the harder for family status. If non-traditional family members are entitled to marital and parental rights then they should be entitled to marital and parental status. Affording them something less not only leaves alternative family members with something less; it undermines the institutions of marriage and parenthood for everyone. 